\section{J D E}

Journal of Developing Economies

\section{JDE (Journal of Developing Economies)}

https://e-journal.unair.ac.id/JDE/index

\title{
ECONOMIC DETERMINANTS OF GROWTH ACCELERATION DURING COVID-19 PANDEMIC: A COMPARATIVE STUDY BETWEEN INDONESIA, THAILAND, AND VIETNAM
}

Raden Mas Try Ananto Djoko Wicaksono*1,2 Rina Putri Rinaldi ${ }^{3}$

\footnotetext{
${ }^{1}$ Department of Law, Universitas Gadjah Mada, Indonesia

2 Department of Public Policy, School of Government and Public Policy (SGPP), Indonesia

${ }^{3}$ Department of Accounting, Universitas Gadjah Mada, Indonesia
}

\section{ABSTRACT}

This paper analyzes the determinants of economic growth acceleration in Indonesia, Thailand, and Vietnam. It aims to reveal Thailand's plausible explanations and Vietnam's development success compared to Indonesia during the COVID-19 pandemic. This research provides an in-depth study parallel to a case study by using comparable variables. It examines six determinants: natural resources, investment, population growth, social-culture, human resources, and political. The evidence exhibits Vietnam has better conditions in all determinants compare to Indonesia and Thailand. Lessons learned from its development experiences could improve Vietnam's successful strategy with previous outbreaks to impact the current economic development.
\end{abstract}

\section{ARTICLE INFO}

Received: July $19^{\text {th }}, 2020$

Revised: November $4^{\text {th }}, 2020$

Accepted: May $8^{\text {th }}, 2021$

Online: June $1^{\text {st }}, 2021$

*Correspondence:

Raden Mas Try Ananto Djoko

Wicaksono

E-mail:

tryananto.wicaksono@gmail.com

Keywords: COVID-19 Pandemic, Economic Growth, International Political Economic

\section{JEL : A10, A11, B27, F13, F21, F5, F52}

To cite this document: Wicaksono, R. M. T. A. D., \& Rinaldi, Rina P.. (2021). The Determinants of Indonesia's Coal Exports Demand to Six Asian Countries. JDE (Journal of Developing Economies), Vol. 6(1), 12-46

\section{Introduction}

On 31 December 2019, the World Health Organization (WHO) China Country Office informed of cases of pneumonia of unknown etiology (unknown cause) detected in Wuhan City, Hubei Province of China (WHO, 2020b) the WHO China Country Office was informed of cases of pneumonia of unknown etiology (unknown cause. On January 5, 2020, WHO published the first Disease Outbreak News on the new virus.

On March 11, 2020, WHO declared the new virus known as Coronavirus (COVID-19). It becomes a pandemic with over 118,000 cases of the coronavirus illness in over 110 countries and territories around the world (Ducharme, 2020) and the sustained risk of further global spread, especially for business activities.

\footnotetext{
JDE (Journal of Developing Economies) p-ISSN: 2541-1012; e-ISSN: 2528-2018

DOI: $10.20473 /$ jde.v6i1.20834

Open access under a Creative Commons Attribution 4.0 International

(CC-BY)

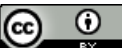


On 30 June 2020, the total number of coronavirus cases in Southeast Asian countries has reached 150,571, with most cases reported in Indonesia and the Philippines. Meanwhile, Thailand confirmed the total number of infections in the country to 3,171 . In Vietnam, the total number of confirmed cases stood at 355, while 335 of them have recovered (Hospita, 2020). While the region's tally is still far off the hundreds of thousands, compared to the U.S. and some European nations (Lee, 2020).

The impact of COVID-19 has led the global economy to shrink. The coronavirus pandemic's hit to economic activity has led to many disasters, especially in the tourism industry. In 2010, the travel and tourism industry contributed just 97.3 billion U.S. dollars to Southeast Asia's GDP. Comparatively, the travel and tourism industry contributed over 393 billion U.S. dollars to the GDP in Southeast Asia in 2019 (Statista, 2020).

However, in the first quarter of 2020, Indonesia's tourism and commodity export revenues is an estimated decline that resulted in the current transaction deficit reaching 2.9 percent of the gross domestic product (GDP) (Kementerian Keuangan RI, 2020). The closures have also impacted most sectors of the Thai workforce, with more the 7.7 million working in tourist and its chain industries (Vilailert, 2020). Meanwhile, over 60 percent of Vietnam's experience for international tourists and domestic tourists may be decreased by 80 percent due to fears of this deadly virus in March 2020. An estimated loss of between $\$ 5.9$ and $\$ 7$ billion for Vietnam's tourism in the first quarter of 2020. The Asian Development Bank's recent report showed that Vietnam would lose 0.41 percent of GDP because of the coronavirus outbreak (T. Nguyen, 2020).

Based on the descriptions above, we can understand that the tourism industry's importance as one of the contributions to GDP. However, some countries still grew positively but declined when compared to the previous quarter. Regardless of the COVID-19 pandemic's impact, Vietnam is forecast to be one of the fastest-growing economies in Southeast Asia. According to the Asian Development Bank (ADB) Outlook 2020 report published on April 3, 2020, Vietnam's economic growth will decline sharply to 4.8 percent in 2020 but bounce back up to 6.8 percent in 2021, as a result of high domestic demand, strong manufacturing, and processing industry, and high Foreign Direct Investment (FDI) (Ha, 2020).

In Indonesia, the economy grew 2.97 percent in the first quarter of 2020 as household spending and investment growth plunged, dragging down the country's economy to its weakest growth since 2001. It began large-scale social restrictions (PSBB) to curb the spread of the virus. But, The Asian Development Bank (ADB) projected Indonesia's gross domestic product still grow 2.5 percent (Akhlas, 2020). Compare to the International Monetary Fund (IMF) and the World Bank on economic projections for Asia show that only three countries are estimated to grow above $0 \%$ or post positive growth, namely Indonesia, China, and India (CABINET SECRETARIAT OF THE REPUBLIC OF INDONESIA, 2020).

Meanwhile, Thailand's GDP forecast in 2020 cut to -4.8 percent due to the impact from COVID-19 or even much worse than peers owing to the high reliance on tourism and export, with tourism services, hotel, and air transportation as the most affected sectors (Ha, 2020). As a comparative, look at each country's forecast GDP growth rates in Southeast Asia as per ADB in Figure 1 below. Focus on Indonesia and Vietnam that predicted positive growth and compare with Thailand that expected to be negative this year. 


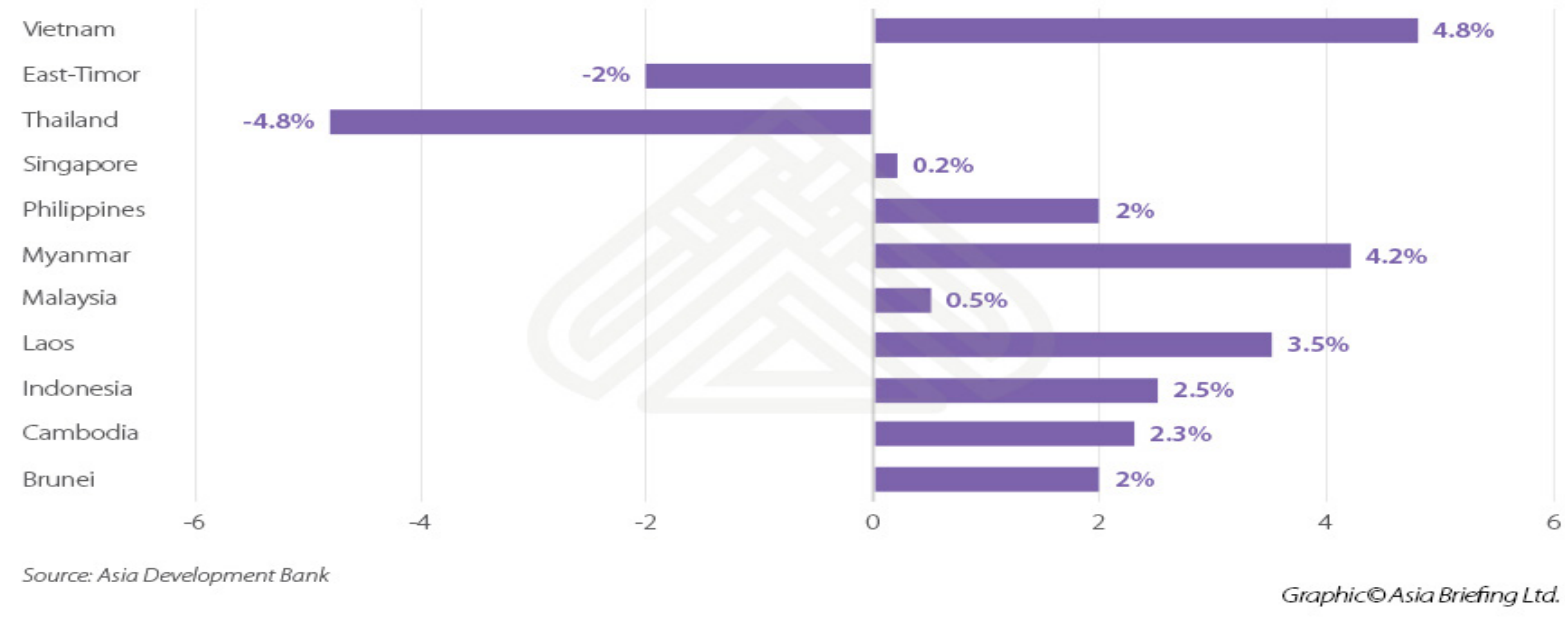

Figure 1: Prediction of GDP Growth Rate in 2020 of Southeast Asia

Source: Vietnam Briefing (2020)

For a comparative study purpose, Thailand and Vietnam as the best countries to be weighed with Indonesia due to some similarities they have, as the following:

1. Geographic location, the countries lie in South-East Asia region.

2. A regional organization is the member of the Association of Southeast Asian Nations (ASEAN), a regional grouping that promotes economic, political, and security cooperation.

3. Agriculture countries, agriculture are critical sectors throughout Southeast Asia, and the region's diverse markets include some of the world's largest agricultural exporters, such as Indonesia, Thailand, and Vietnam.

4. History of military domination in politics, Indonesia, the new regime led by Suharto, would last from the coup in 1965 until 1998 as the military influence. Vietnam, under President Diem (1955 - 1963), military officials who focused solely on military matters were never promoted nor given special attention or treatment; only the officers who concentrate on the political facet of their positions were able to be upgraded and move up in the ranks. Thailand, Chatichai Choonhavan was a Thai Army Officer as the Prime Minister (1988 - 1991).

5. The tourism industry, Indonesia, Thailand, and Vietnam has GDP dominant contribution from travel and tourism. The tourism industry has flourished and become a significant driver of the economy and a central feature of the government's economic growth strategy, such as Bali (Indonesia), Phuket (Thailand), and Ha Long Bay (Vietnam).

6. Natural resources, the ASEAN region is endowed with rich natural resources that sustain essential life support systems both for the region and the world. Apart from providing water, food, and energy, these natural resources play a crucial role in sustaining a wide range of economic activities and livelihoods.

7. Asian financial crisis, the Asian financial crisis was a period of financial crisis that gripped much of East Asia and Southeast Asia beginning in July 1997. The situation raised fears of a worldwide economic meltdown due to financial contagion that started in Thailand affected Indonesia and little effect on Vietnam. 
Thus, through this analysis, the authors would explore more economic determinants of growth acceleration during COVID-19 in Indonesia compared to Thailand and Vietnam. Putting a compelling mixture of policy responses in place will help deal with the pandemic and build momentum for future growth. Each country has its policy to deal with the pandemic; the decision will impact the political and security, and economic activity.

\section{Literature Review}

In the history of economic thought, the classics put forward theories on economic growth before 1870. Adam Smith, David Ricardo, Robert Malthus, and Jhon Stuart Mill pioneered this classical growth theory. The Classical Class about the idea of economic growth includes two sectors of the economy, namely consumers and producers, there is no government intervention, and economic development depends on the market mechanism (Amalia, 2007).

Two points will discuss in the literature review related to the factors that influence economic growth according to (Jhingan, 2008): Economic Factor and Non-Economic Factor. The Economic factors consist of three essential factors that are the natural resources, investment, and population growth. Meanwhile, Michèle Flournoy, as the head of the geopolitical risk at Beacon Global Strategies, believe there are factors six-determine coronavirus containment, or devastation consist of Quality of Health and Public Health System, Culture and social cohesion, Political and Administrative Factors (Security) (Flournoy \& Morell, 2020). This paper utilizes the seminal work of Michèle Flournoy's perspective as non-economic factors.

\section{Economic Factor: Natural Resources}

The main factor influencing the development of an economy is natural resources. According to Lewis, a natural resource's value depends on its usefulness. Its usefulness is always changing all the time due to changes in new techniques or inventions (Jhingan, 2008, p.86). David Ricardo believes that the existence of fixed factors of land production would hamper economic growth. First revealed Ricardo's theory was in his book entitled "The Principles of Political Economy of Taxation," published in 1917 (Arsyad, 1999). Natural and environmental resources (SDAL) are assets that produce flows of goods and services, both those that can be consumed directly or not to meet human needs. Natural resources are in some cases also public goods whose ownership rights are not established (Fauz, 2009).

\section{Economic Factor: Investment}

The Harrod-Domar economic growth model is built on the experience of developed countries. The model is based on an advanced capitalist economy and seeks to evaluate or study steady growth requirements from developed countries. Harrod and Domar provide an essential role in forming investment in a country's economic growth process. Investment is considered a necessary factor because it has two characters or two parts simultaneously influencing the economy. First, investment acts as a factor that can create income, meaning that investment controls the demand side. Second, investments can enlarge the economy's production capacity by increasing capital stock, meaning that investors will affect the supply side (Tarigan, 2006).

Therefore, if a country's economy wants to advance, it must invest in economic activities. The investment could improve the ability to create or add value to the use of life. Investment is not only in physical form but also non-physical, especially in improving human resources quality. Economic growth also depends on the amount of investment that can drive the economy (Kuncoro, 2006). According to Todaro, investment as an important role in driving the nation's economic life because capital formation increases production capacity increases national income, and creates new jobs; in this case, will further expand employment opportunities (Todaro, 2000). 
Wicaksono, R. M. T. I Economic Determinants of Growth Acceleration During Covid-19 Pandemic: A Comparative Study Between IndoneA. D., et al. sia, Thailand, and Vietnam

\section{Economic Factor: Population Growth}

Adam Smith was the economist who first put forward the laissez-faire policy and was an economist who focused a lot on development issues. This can see In his book entitled "An Inquiry into the Nature and Causes of the Wealth Nations" in 1776, which proposed the process of systematic economic growth. The core of the process of economic growth, according to Smith, is divided into two main aspects, namely total output growth and population growth (Arsyad, 1999). In Smith's perspective on Population growth encourage economic development because it can expand markets. Whereas Ricardo and Malthus, the rapid development of the population will double the people in one generation, the impact can reduce the level of economic growth to a lower level. At this level, workers will receive very minimal wages or subsistence wages (Sukirno, 2006).

\section{Non-Economic Factor: Quality of Health and Public Health System}

In instrumental terms, health impacts economic growth in several ways. For instance, good health quality will reduce production losses due to worker illness. It will increase the productivity of adults as a result of better nutrition and lowers absenteeism rates. In sum, health affects economic growth directly through labor productivity and the financial burden of illnesses (WHO, 2001). Quality is described in some sectors as value to users of goods and services. An early driver of the private industry's quality improvement movement was to increase value by reducing costs while providing better goods and services. The availability of timely and reliable data (e.g., health status, financial, outcomes, etc.) will diminish barriers to determining public health services' value (Public Health Quality Forum, 2008).

The impact of this national public health quality movement will be multifaceted. It will promote quality along all dimensions of the system, focusing on population increase desired health outcomes and conditions in which the population can be healthy and foster health equity (Public Health Quality Forum, 2008). Poor nutrition has many other consequences, too many to quantify, including effects on the cognitive capacity of the population (Rubalcava \& Teruel, 2004).

\section{Non-Economic Factor: Culture and Social Cohesion}

In developing countries, there are social and cultural traditions that do not support economic development. Therefore, for growth, there must be a free society with a robust middle class that can increase income through trade and commerce. These two factors produce modern economic growth in developed countries.

Social construct has substantial repercussions on the economy. The social organization of individual countries limits their economic development, and social pathology is present in many countries (Tekic \& Katalinic, 2012). According to Harrison and Huntington, the analysis of social factors helps to understand human behavior concerning consumption, savings, invitational system, expectations, and attitude towards the economic circumstances, which also significantly impact economic growth (Abramson, Harrison, \& Huntington, 2001).

\section{Non-Economic Factor: Political and Administrative}

Political and administrative factors also impact economic growth. Weak political and organizational structures are a significant obstacle to economic growth. Such a clean and robust administration can fully stimulate economic growth (Sukirno, 2008). In this paper, a split of political and administrative factors into critical decision-making, border issues, and leadership factors to determine coronavirus containment or devastation.

It comes when studying their impact on the economic growth and understanding the elements essential as government and others struggle to deal with COVID-19 and consider how to better prepare for future pandemics (Flournoy \& Morell, 2020). 


\section{Data and Research Methods}

This research utilizes Labovitz et al., (1971) seminal work on comparative social inquiry to understanding the analysis. The book entitled "The Logic Of Comparative Social Inquiry" as comparative Studies in Behavioral Science emphasizes cross-disciplinary studies. Although it works within the perspective of a single discipline are included, in its scope, the series consists of books of theoretical and methodological interest and studies based on empirical research (Labovitz et al., 1971).

Labovitz et al., (1971) suggest two comparative inquiry methods: the 'Most Similar Systems Design' (MSSD) and the 'Most Different Systems Design' (MDSD). The former focuses on "intersystem similarities and intersystem differences" while the latter focuses on the "intrasystem" level. Johan Galtung suggested this in a somewhat less detailed. The paper utilizes the "most similar systems" design.

MSSD, according to John Stuart Mill, is a comparison method that identifies the main features, which then observes the results of the political system. Political comparison is used to describe political phenomena and certain events in a particular country or specific groups of countries. Political phenomena that occur in several countries on a small scale are then compared to produce similarities and differences from the background of taking a political policy and the consequences resulting from that policy (Landman, 2003).

MSSD designs focus on concomitant variation; cannot single out the experimental variables. MSSD compares two or more cases with comparable variables whose values are the same, but the resulting output is different. The key is to identify what factor leads to Y's different outcomes when the cases appear somewhat similar in most regards (Landman, 2003:26-32). This research will identify the aspects of Economic and Non-economic Factors as mentioned above in the literature review.

\section{Finding and Discussion}

World Bank (2020) describes both the immediate and near-term outlook for the pandemic's impact and the long-term damage it has dealt with prospects for growth. The baseline forecast envisions a 5.2 percent contraction in global GDP in 2020, using market exchange rate weights. It will be the deepest global recession in decades, despite governments' extraordinary efforts to counter the downturn with fiscal and monetary policy support (World Bank, 2020a).

According to Statista, early estimates predicted that major economies would lose at least 2.4 percent of the value of their gross domestic product (GDP) over 2020, leading economists to already reduce their 2020 forecasts of global economic growth down from around 3.0 percent to 2.4 percent. However, these predictions before COVID-19 became a worldwide pandemic and before implementing lockdown to stop the virus's spread (Statista Research Department, 2020b).

Meanwhile, World Bank predictions on Global GDP is expected to decline by 2.1 percent, while developing countries' GDP is expected to decrease by 2.5 percent and high-income countries by 1.9 percent. The most significant GDP losses under the global pandemic scenario are expected in East Asia and Pacific (EAP) countries due to their relatively deep integration through trade and direct impact on tourism, e.g., Thailand with 3 percent and Vietnam 2.7 percent (Maliszewska, Mattoo, \& Mensbrugghe, 2020).

\section{Economic Factor: Natural Resources}

According to Singer (1950) and Prebisch (1950), the producing and exporting natural resources, including essential agricultural products by countries, would lead to a deterioration of the terms of trade in these countries in the long-term (Singer, 1950; Prebisch, 1950). 
In the long-term, this means that developing countries that concentrate on the production of natural resources have to exchange more and more of their primary products against the industrially produced products of developed countries.

In the first quarter of 2020, Indonesia's economy recorded a contraction of 2.41 percent compared to the first quarter of 2019. Most business fields experienced a decline in COVID-19. Amid several business fields that experienced negative growth, agriculture, forestry, and fisheries experienced positive growth.

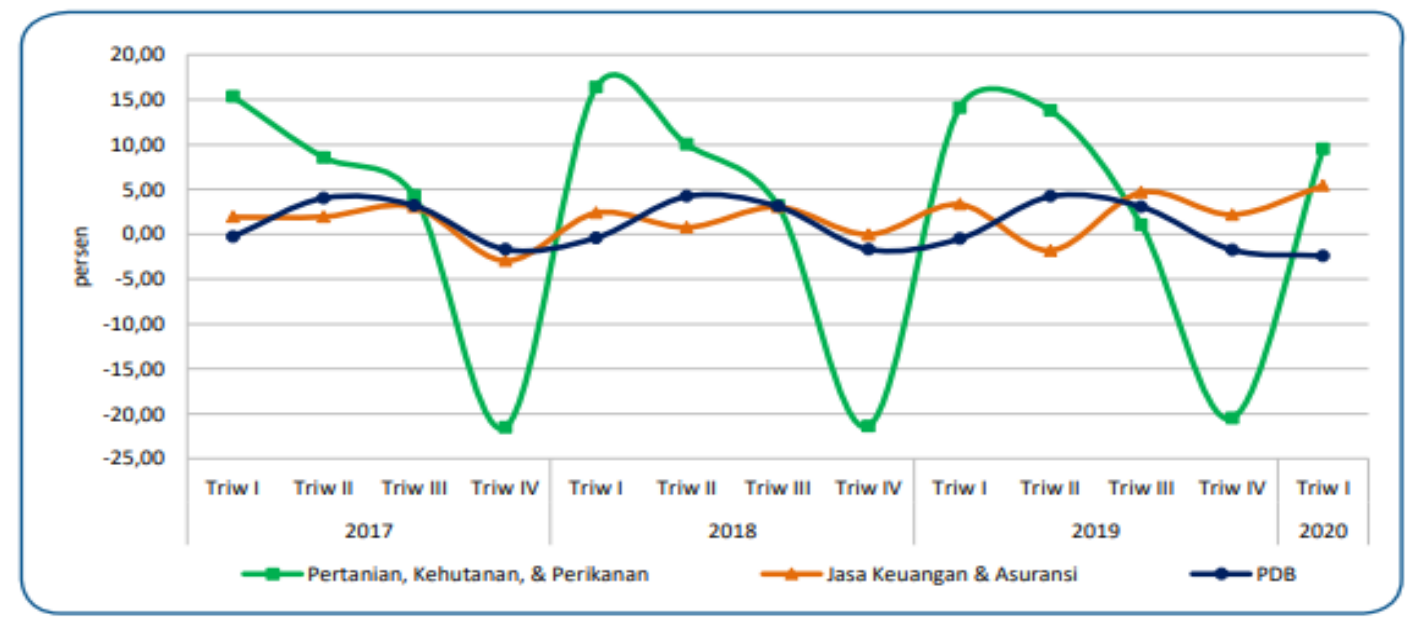

Figure 2: GDP Growth: Agriculture, Forestry \& Fisheries compared to Financial Services \& Insurance (q-to-q)

Source: Badan Pusat Statistik (2020)

Compared with business fields, Financial Services and Insurance experienced positive growth of 5.39 percent, Information and Communication by 2.97 percent, Health Services and Social Activities by 1.09 percent, and Real Estate by 0.52 percent, Agricultural, Forestry, and Fisheries Business Fields had the highest percentage of positive growth with a value of 9.46 percent.

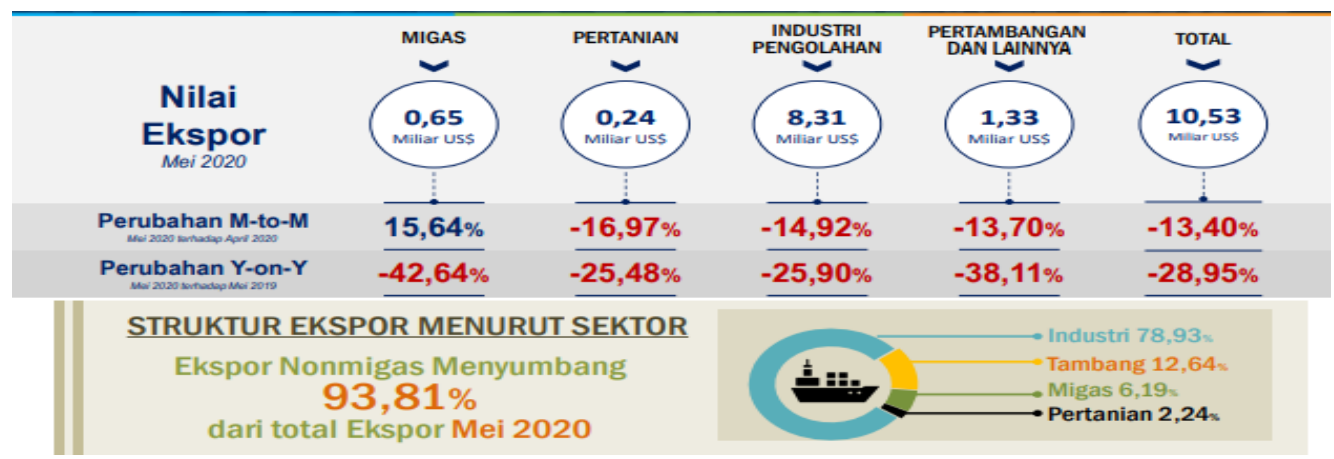

Figure 3: Indonesia Score Export

Source: Badan Pusat Statistik (2020)

Based on the data above, the Central Statistics Agency issued data on Indonesian exports and imports. Industries that use natural resources are still the most significant contributor to Indonesia's exports until May 2020. Furthermore, the Indonesia Minister of Health ("MOH") enacted MOH Regulation No. 9 of 2020 regarding Large-Scale Social Distancing to Accelerate the Response to COVID-19 to provide further details on the implementation of largescale social distancing measures (Menteri Kesehatan RI, 2020). According to Section D.2(b) of 
the Annex to $\mathrm{MOH}$ Reg. No.9/2020 exempts several businesses or institutions that providing essential goods and services from closure under the large-scale social distancing programs. In particular, Section D.2(b)(3)(c) of the Annex to MOH Reg. No.9/2020 provides that the production of oil and gas, coal, and minerals are among those businesses exempted from workplace closures under social distancing restrictions, which means oil and gas upstream activities are allowed to continue during the COVID-19 pandemic (Mahiddin \& Wirabuana, 2020).

The realization of PNBP (Penerimaan Negara Bukan Pajak) or known as Non-tax revenue until the end of February 2020, reached Rp38,62 trillion or 10.52 percent of the target in the Budget 2020. The achievement of PNBP realization is mainly dominated by the completion of PNBP SDA and other Non-tax revenue, each amounting to Rp20,92 trillion and Rp15,98 trillion. The culmination of the Non-tax revenue of Natural resources of oil and Gas, Indonesian Crude Price (ICP) period from January to February 2020 recorded at USD61,00/barrel or higher USD2,07/barrel compared to the same period in the previous year of USD58,93/barrel (Kementerian Keuangan RI, 2020).

Meanwhile, Vietnam is much helped by the digital technology manufacturing industry and high technology products. This industry is Vietnam's primary income source and is a necessary commodity when viewed from export value and market share. Nevertheless, Vietnam also still relies on natural resources as a source of income. In early 2020, Vietnam received foreign investment in the electricity, gas steam, water production and distribution, retail and wholesale, and real estate sectors (J. Nguyen, 2020).

Jan-Jun 2019 Jan-Jun 2020

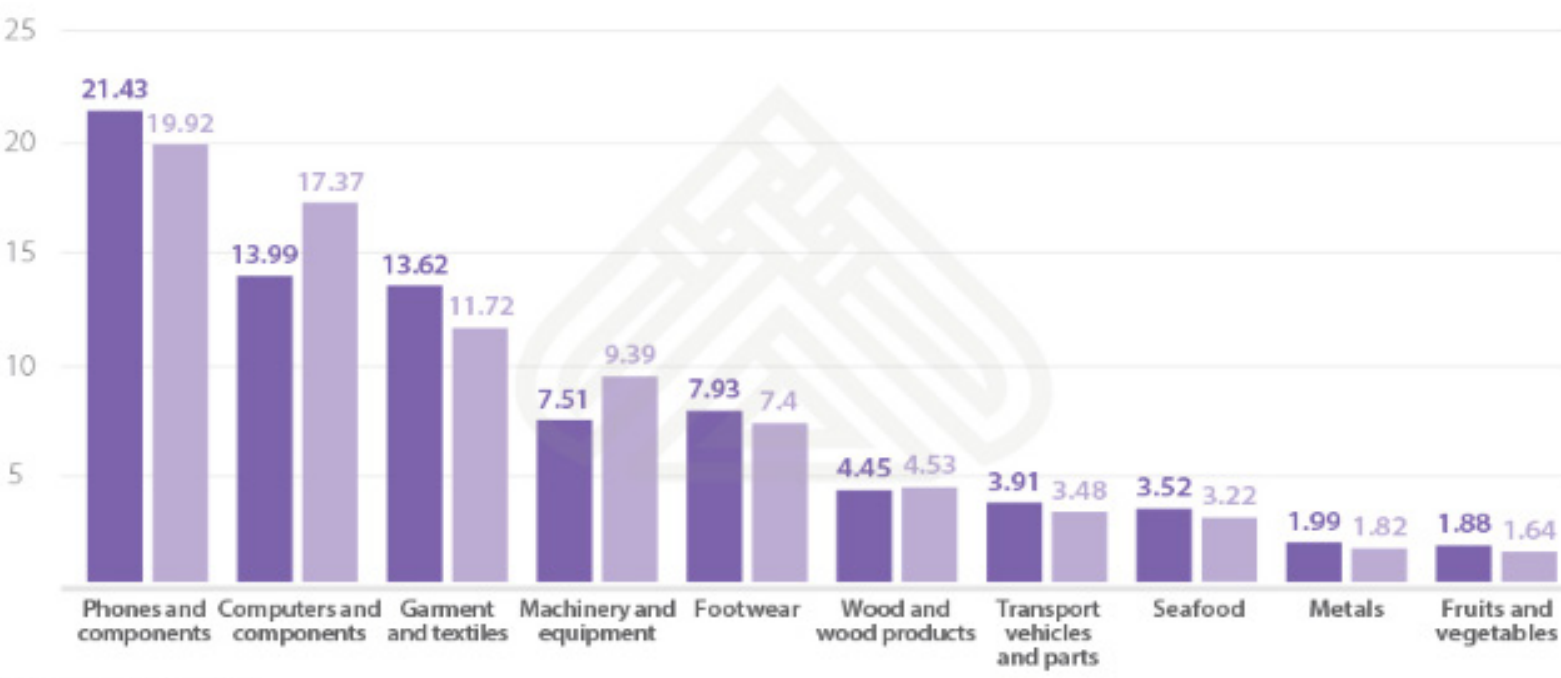

Figure 4: Export Value of Vietnam's Largest Comodities (billion U\$)

Source: Nguyen (2020)

In early 2020, Vietnam's export value fell by 6.7 percent or equal to the US $\$ 79.8$ billion if compared to the first quarter of 2019. Although during the COVID-19 Pandemic, Vietnam still experienced a trade surplus of US $\$ 14.2$ billion, this surplus contributed positively to the US $\$ 4$ billion to all Vietnam's trade balance (J. Nguyen, 2020). Vietnam's growth model is heavily reliant on trade in natural resources for three reasons, according to Friedrich Ebert Stiftung (2016): First, the government's focus on natural resource exploitation is one of the leading development strategies. Secondly, as a result of the exploitation strategy, huge capital investment and investment in advanced technology occur in the exploitation and post-processing of natural resources, with only limited success. The last makes many private companies export natural resources on a low technological level (Herr, Schweisshelm, \& Vu, 2016). 
Wicaksono, R. M. T. I Economic Determinants of Growth Acceleration During Covid-19 Pandemic: A Comparative Study Between IndoneA. D., et al. sia, Thailand, and Vietnam

As a result, European Union (EU) and Vietnam Free Trade Agreement impacted Vietnam's Competitive Gains; through EU FDI has targeted sectors such as oil and gas exploration with 19 projects worth 2.5 billion USD (Deshmukh, 2020).

Besides, countries that rely on the tourism sector, like the Thai economy, experience a crisis due to the COVID-19 pandemic. Thailand's dependence on the tourism sector made the economic situation much worse than other countries in Southeast Asia. Thailand's GDP was originally 1.8 percent contracted to -0.3 percent due to pandemic (Deloitte, 2020). Despite having abundant natural resources, Thailand cannot use them well to improve the country's economy. The World Bank estimates that Thailand's economic growth will last for around two years; this depends on the policies of various countries regarding mobility restrictions, international travel restrictions, and trade and supply chain disruptions (World Bank, 2020b).

Thailand, a country rich in natural resources, has played a significant role in supporting local livelihoods and driving economic growth. Forests, watersheds, marine environments, and mineral resources have all been instrumental in helping the Thai manufacturing, export, and tourism industries (Open Development Mekong, 2020). According to World Bank, Thailand's economy shrank by 1.8 percent y-o-y in Q1 2020, with all sectors contracting: agricultural production by 5.7 percent, industrial production by 1.9 percent, and services sector by 1.1 percent y-o-y. Agricultural production continued declining, driven by reduced yields of major crops such as paddy, sugarcane, maize, cassava, and oil palm on account of continued dry weather (Theparat, 2020). Table 1 below shows that the most significant impacts are on exports of Agriculture and Traded Tourist Services, with minimal impact on natural resources based on World Bank report estimated 2020.

Table 1: Output Implications of Amplified Global Pandemic-Cumulative Impacts (\% Deviations from The Benchmark)

\begin{tabular}{lccc}
\hline & Agriculture & Natural Resources & Traded Tourist Services \\
\hline Indonesia & -2.70 & -0.61 & -8.84 \\
\hline Thailand & -3.06 & -2.91 & -14.64 \\
\hline Vietnam & -3.06 & -0.72 & -8.99 \\
\hline
\end{tabular}

Source: Maliszewska et al (2020)

Furthermore, the COVID-19 pandemic was also suspected of impacting Indonesian, Vietnam, and Thailand's natural resources trade, including agriculture with China. During this time, Indonesia's export of palm oil was one of China's largest export contributors. However, in February 2020, the realization only reached 84,000 tons. This value is very far from the previous month's completion of January 2020 of 487,000 tons and in the same period of 2019 that reached 371,000 tons (Novika, 2020).

While Vietnam's export value in the first five months of 2020 saw a decline of 4.1 percent year-on-year and was valued at US\$15.5 billion due to the COVID-19 pandemic. China is Vietnam's largest exporting market of agricultural products, with export turnover at $\$ 3.7$ billion, a 15.5 percent drop in value, closely followed by the US and the EU, reaching $\$ 3.4$ billion and $\$ 1.6$ billion, respectively. According to Nguyen Quoc Toan, Director of the MARD's Agro Processing and Market Development Department, the new strategy is focused on resolving technical barriers in agricultural trade and expanding and diversifying markets through negotiations with trade partners (MARD, 2020).

During the last decade, China had significantly increased imports of fresh produce from its neighboring countries, such as Thailand, Vietnam, and Myanmar. Currently, Thailand's exports over a fourth of its agricultural products to China Exports of Thai agricultural products have declined by $21-24 \%$ of total export volume (Thaichareon, 2020). Since October 2019, Thailand's exports have not recovered, falling 4.5\% year-on-year. Pimchanok Vonkorpon, director-general of the Trade Policy and Strategy Office, the economic planning unit of the Com- 
merce Ministry, stated that the impact of protectionist measures has negatively impacted most of Thailand's key trading partners, leading to lower exports to those countries (Arunmas, 2020).

\section{Economic Factor: Investment}

According to Jhingan (2008), the investment will influence the development of a region. The impact is called the spread effect, when an asset invested in an area brings positive results for other areas, such as the growth of complementary or supporting industries for the leading sectors in the investment center area (Jhingan, 2008). Thus, to remedy the economic impacts of COVID-19 and support the country's anticipated growth after the crises abate.

The Vietnamese economy has been remarkably resilient. Foreign investors are still interested in investing, with over USD 12 billion of foreign direct investment registered between January and April 2020 (Morisset, 2020). For EU foreign investors, the move signals a positive development in Vietnam's business environment. FDI in Vietnam amounts to 38.2 billion USD (Ministry of Planning and Investment Vietnam, 2019). On June 29, Vietnam ratified a landmark trade deal with the European Union. It took effect on July 2020; the EU will lift 85 percent of its tariffs on Vietnamese goods, gradually cutting the rest over the next seven years. Vietnam will raise 49 percent of its import duties on EU exports and phase out the rest over ten years (Dinh, 2020). COVID-19 has given the EU a hard lesson about being dependent on China. The negative impact of relying too much on China's product value chain makes the EU lack materials. Therefore, when Vietnam's factories reopened, it comes at the right time as all parties realize they need to pivot and restructure to diversify the supply chain.

Another reason foreign investors are still interested in investing in Vietnam because of the cheap labor. Since 2000, Vietnam has grown at an average of 6.2 percent per year, gaining fame worldwide as one of the world's most inexpensive deliveries. Hanoi and Ho Chi Minh City's minimum wages for only VND 3.9 million (USD 172) per month (Jennings, 2017). Therefore, low-cost labor has been positioned in Vietnam as the premier hub for labor-intensive business operations, particularly manufacturing. Many big foreign manufacturers, such as Samsung, LG, Intel, Nike, and Adidas, have chosen Vietnam as their destination due to the country's low labor costs (Voice of Vietnam, 2019).

In the case of Samsung, it moved to Vietnam during the COVID-19 Pandemic; the main plant of Samsung is near Daegu, the epicenter of COVID-19 in Korea at the end of February 2020. When the disease was discovered among its workers, the factory immediately halted all activities for several days. Samsung then decided to switch part of its smartphone production to Vietnam, where it operates in other factories (Financial Times, 2020a). The decision supported by Vietnam's public health response is impacted on the entire decision for the investor to stay, the combination of decisive government action (schools have been closed since late January, for example), and careful adherence from the broader public. As a result, Vietnam currently has fewer than 300 confirmed cases versus over 600,000 in the US (Thai, 2020).

Considered successful in tackling COVID-19 well, Vietnam was able to restore the country's economy. The Ministry of Planning and Investment (MPI) provided information on Vietnam's performance during the middle of 2020. There was the US $\$ 8.65$ billion until June, equivalent to $95.1 \%$ of foreign investment projects. Countries that are the top investors are Singapore, Thailand, China, Japan, and South Korea. The manufacturing and processing, electricity, gas steam, water production and distribution, retail and wholesale, and real estate sectors contributed $25.5 \%$ of the total foreign investment in Vietnam.

In Thailand, the total value of FDI applications was 71.38 billion baht during the first quarter of 2020, which means a 41 percent decline for the same period in 2019. Of that, foreign investment accounted for $\mathbf{2 7 . 4 3}$ billion baht or 38 percent of the portfolio. Thailand has three primary FDI sources from Japan, China, and Hong Kong (Macan-Markar, 2020). The 
Wicaksono, R. M. T. I Economic Determinants of Growth Acceleration During Covid-19 Pandemic: A Comparative Study Between IndoneA. D., et al.

COVID-19 Pandemic has left a mark on a critical sector of Thailand's FDI, automobiles. The local market leader, Toyota Motor, has shut three assembly plants (The Nation Thailand, 2020). Mitsubishi Motors and Isuzu Motors, which rank second and third in sales, also suspended production (Muramatsu \& Jibiki, 2020). The Japanese automakers watched as Thailand's auto sales dropped 17 percent in February 2020. When the Thai government imposed an emergency to contain the virus's spread in March, auto sales plunged by 42 percent. By April, car sales had dropped by 65 percent (Nikkei Asia, 2020). During COVID-19, the Thailand Board of Investment approved 41.8 billion Baths, equivalent to the US $\$ 1.35$ billion. The investment came from 5 large-scale investments by Sammitr Group, Thai Oil PCL, Envico Company Limited, B. Grimm Power (Laem Chabang), 1 Company Limited, and Bangkok Arena Company (Thailand Board of Investment, 2020).

Compare to Vietnam and Thailand, Indonesia is relatively unattractive to foreign investors. As Figure 5 shows below, although its Ease of Doing Business rankings has improved significantly since 2014, this has been insufficient to catch up with most of its peers. Openness to FDI has been declining before reversing in 2015. Both indicators show no improvement since 2017, which is rather unfortunate considering its Southeast Asia neighbors' gains in the same period (The World Bank, 2020a). The Investment Coordinating Board (BKPM) announced that Indonesia's FDI fell 6.9 percent compared to the same period in 2019. From April to June 2020, the value of Indonesia's FDI was only Rp 97.6 trillion, equivalent to the US \$ 6.67 billion. This value is very far from the BKPM estimates that it hopes to attract Rp 200 trillion in the second quarter of 2020 (Rahman, 2020b).

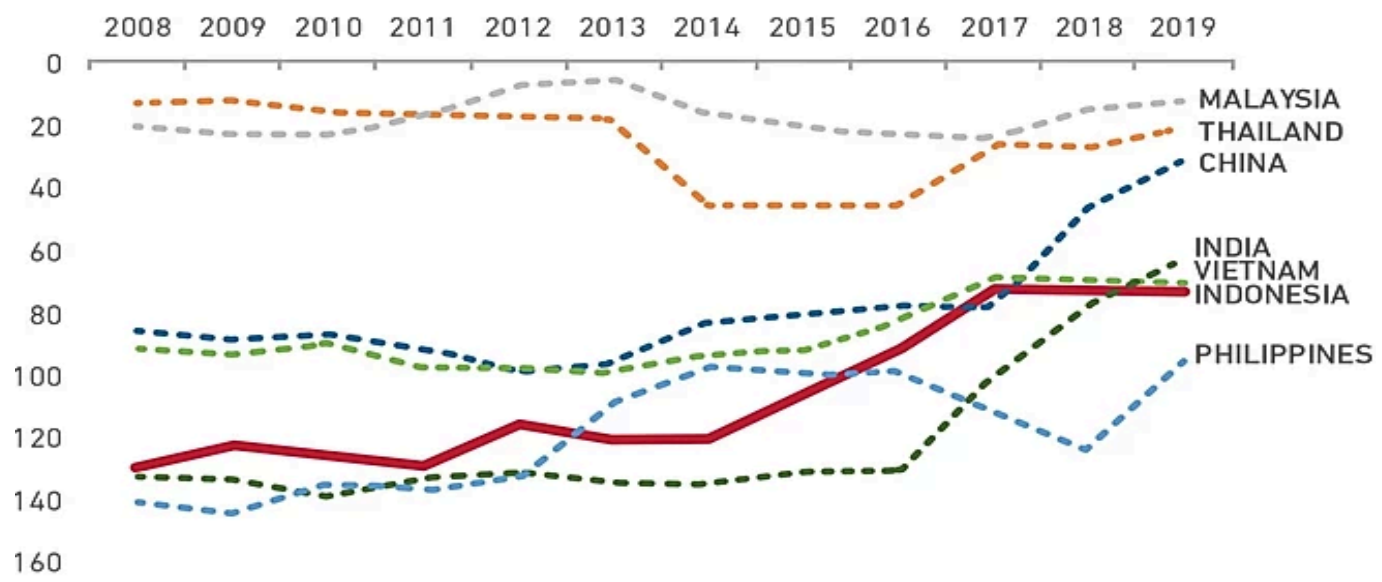

Figure 5: Ease of Doing Business

Source: The World Bank (2020)

However, according to Indonesia Investment Coordinating Board (BKPM), the first quarter (January-March) of investment realization data in 2020 reached Rp 210.7 trillion or equivalent to an 8.0 percent increase in the same period 2019. Investment realization of first-quarter contributed 23.8 percent to the 2020 target investment realization of Rp 886.1 trillion (BKPM, 2020a). Several countries have contributed to Indonesia's FDI in the first quarter of 2020, here's the top 5 of FDI in Indonesia: (1) Singapore, still consistently ranked as the leading country of FDI origin for Indonesia. In the first-quarter of 2020, with US\$ 6.52 .7 billion, amounting to 40 percent of the total FDI realization in Indonesia. (2) China, in the first quarter of 2020, China placed second with a total of US\$ 1.3 billion of foreign investment. Most notably, China's investment in Indonesia's transportation, industry, and tourism. (3) Hong Kong invested US\$ 0.6 billion throughout the first quarter of 2020. (4) Japan, in the first quarter of 2020, Japan has invested US\$ 0.6 billion. Some of Japan's sectors are electricity, real estate, gas, and industry. (5) In the first-quarter of 2020, the foreign investment that Indonesia gained from Malaysia reached US\$ 0.5 billion (BKPM, 2020b). 
Furthermore, even though it seems unattractive for FDI, Domestic Investment (DDI) still supports economic growth. According to the Chairman of the Indonesia Investment Coordinating Board (BKPM), the realization of investment in the first quarter of 2020 reached Rp. 210.7 trillion, or grew 8 percent compared to 2019 from the One-Stop Investment and Integrated Services Office (DPMPTSP) from 34 provinces throughout Indonesia. The realization of investment in the second quarter of 2020 is sure to decline. Likewise, the 2020 investment realization target will be adjusted to the conditions that occur. Therefore BKPM and DPMPTSP Province and Regency/City must continue to consolidate to encourage investment realization (BKPM, 2020a).

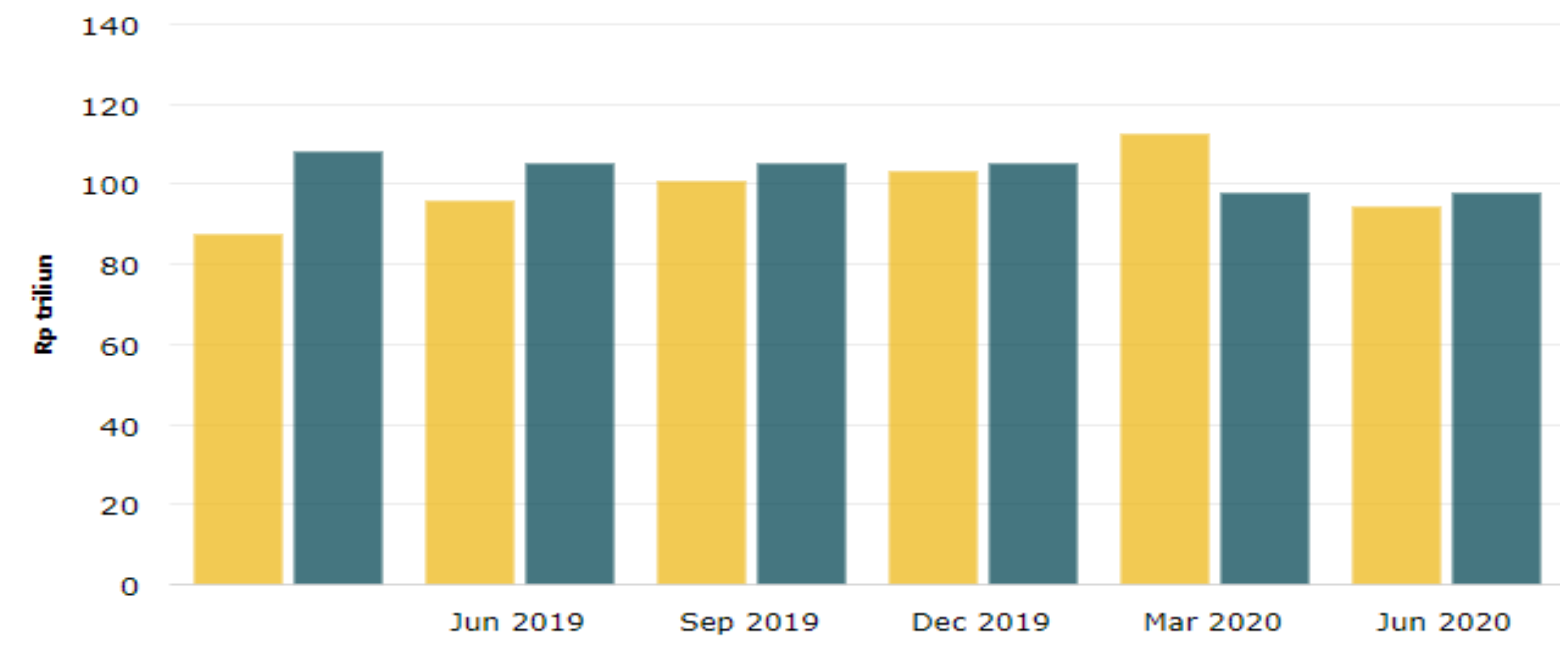

Figure 6: Realization of Indonesia FDI and Domestic Investment

Source: Databoks (2020)

From the data above, for 2020, the total investment coming from Domestic Investment (PMDN) and Foreign Investment (PMA) reaches Rp 191.9 trillion. Compared with the same period in 2019, the value of PMDN and PMA fell by $1.4 \%$ and 6.9 percent, respectively. Unlike the second quarter, which experienced a decline, in the first quarter of 2020, Indonesia's total investment realization increased by 1.8 percent or was valued at Rp 402.6 trillion (Databoks, 2020).

The government implements a "Large Investments Realization Execution" program which aims to increase investment realization. This program will allow the government to oversee large investment projects from the licensing stage to resolve various investment problems in the field. BKPM as program implementers collaborates with ministries/institutions to create a conducive investment climate. This collaboration allows the Ministry of Finance to provide fiscal incentives for investors (BKPM, 2020c).

In times of economic instability, the Indonesian government is aware of the need for governance of government and institutional investment arrangements. Investment governance will form an investment climate that can support accelerated economic growth. The government's seriousness regarding investment governance is then manifested in the stipulation of the Minister of Finance Regulation No. 53 / PMK.05 / 2020 concerning the procedures for government investment. This regulation takes effect on May 19, 2020 (Siallagan, 2020).

\section{Economic Factor: Population Growth}

Population growth affects many phenomena such as the age structure of a country's population, international migration, economic inequality, and the size of a country's workforce. These factors both affect and are affected by overall economic growth (Peterson, 2017). Economic growth is measured by changes in a country's Gross Domestic Product (GDP), which 
Wicaksono, R. M. T. I Economic Determinants of Growth Acceleration During Covid-19 Pandemic: A Comparative Study Between IndoneA. D., et al. sia, Thailand, and Vietnam

can decompose into its population and financial elements by writing it as population times per capita GDP. GDP is a measure of economic output and is also an indicator of national income, which can be defined as total output net of capital depreciation plus net income from sources outside the country (Piketty, 2015).

According to World Economic Forum, by 2030, Asia is expected to contribute roughly $60 \%$ of global growth (ADB, 2017). Asia-Pacific will also be responsible for the overwhelming majority $(90 \%)$ of the 2.4 billion new middle-class members entering the global economy (Financial Times, 2019). The bulk of that growth will come from the developing markets of China, India, and Southeast Asia. On average, the Association of Southeast Asian Nations (ASEAN) population increased annually by 1.6\% between 1980 and 2018 from 355.1 million to 649.1 million. Fertility is one of the significant contributors to population growth. Based on the most recent data (2018) (The ASEAN Secretariat, 2019). Total fertility rates (TFR) are declining over time in all $10 \mathrm{AMS}$, except Indonesia.

However, some of the most rapidly aging countries in the world can be found in Southeast Asia. An aging population shifts the narrative of ASEAN's growth prospects because it means there will be a decline in working-age populations. Countries affected by a growing senior population are building policies to address both the growth of their economies and the rights of the elderly. Living arrangements and family support for older people have become increasingly important (Jong-Wha, 2018).

In Vietnam, government statistics show that 11.3 million older adults, with 1.8 million over 80 (The ASEAN Post Team, 2019). According to the same study, that proportion will rise to about 20 percent by 2038. While the aging population in Thailand, expected to reach 22.8 percent populations in 2035. It is reported that Thailand has 8.6 million people over the age of 65 and will become an aging society by 2021. Over the next 15 years, more elderly Thai people will need healthcare support, raising the annual healthcare spending to THB1.4 trillion (US\$44.8 billion) to meet their needs (The ASEAN Post Team, 2020).

To reduce and offset the impact caused by COVID-19, Vietnam also issued a fiscal stimulus of VND 271 trillion. This amount is equivalent to 3.4\% of Vietnam's GDP. The government applies tax deferral, tax breaks, and exemptions and provides cash for workers and households affected by COVID-19. On the other hand, The State Bank of Vietnam is easing monetary policy to support the country's economy.

Vietnam and Thailand's GDP growth compare to Indonesia is far behind. Indonesia's population is relatively young compared to Thailand and Vietnam, with the median age being 30.2 years in 2017. However, out of around 267.3 million, about 25.1 million Indonesians still live below the poverty line, with approximately $20.6 \%$ of the entire population remains vulnerable to falling into poverty based on March 2019 data (The World Bank, 2020b). Otherwise, Indonesia's nominal GDP is \$1.02 trillion, and the Indonesian economy grew by 5.1 percent in 2019. GDP per capita rose to $\$ 3,871$ - compared to 2000, it was $\$ 857$. In terms of purchasing power parity, Indonesia's GDP is at $\$ 3.50$ trillion (Asia Funds Managers, 2020).

Meanwhile, Vietnam's gross domestic product expanded by 0.36 percent year-on-year in the second quarter of 2020, following a 3.83 percent growth in the first quarter of 2020 (Trading Economics, 2020). However, Vietnam's Ministry of Planning and Investment has discussed possible scenarios and their impact on the country's GDP. If the coronavirus can be contained in the second quarter of 2020, the GDP was projected to increase by only 6.09 percent (Statista Research Department, 2020a).

According to the Thai Bankers' Association (TBA), the Thai economy could suffer a loss of 1.3 trillion baht, representing $7.7 \%$ of GDP, because of damage from the spiraling coronavirus, on par with the economic contraction from the financial crisis of 1997 (Paweewun, 2020). 
The Bank of Thailand (BOT) kept its policy rate steady, as widely expected, and downgraded its 2020 GDP forecast to a contraction of $8.1 \%$ from a 5.3\% decline projected in March (Asia Nikkei, 2020b). Thailand's GDP fell a seasonally adjusted 2.2\% in the first quarter (Q1) - 2020 compared with the previous three months. According to the council's secretary-general, Thosaporn Sirisumphand, The government has stepped in with a stimulus package worth about $15 \%$ of GDP, among the largest in Asia. It's also borrowing 1 trillion baht (\$31.2 billion) that will help sustain Thailand's economy (Yuvejwattana et al., 2020).

Different situation with Vietnam and Thailand, Indonesia recorded as many as 6.88 million unemployed in February 2020. The number of unemployed is 4.99 percent of the total workforce of 137.91 million. The government responds well to the conditions that occur in society by issuing fiscal stimulus expected to encourage economic stability. This stimulus is directed at handling health, economic recovery, overcoming financial difficulties experienced by extreme communities through social safety net for Low-Income Communities (MBR). In the form of electricity subsidies, the government, food staples, the Family Hope Program (PKH), and the Work Card realize other fiscal stimulus forms (Kementerian Keuangan RI, 2020).

According to the Central Statistics Agency data, the result of the 2015 Interdental Population Survey (SUPAS), from the data, obtained information that Indonesia's total population in 2020 was 269.6 million. There are 135.34 million inhabitants of the male population and 134.27 million inhabitants of the female population. If grouped by age group, there are 185.22 million people or 68.7 percent of the total population included in the productive age (15-65 years), 66.05 million people or 24.5 percent including the unproductive age (0-14 years), and 18.06 million lives or 6.7 percent including hopeless age (over 65 years). If according to age group, Indonesia is in the era of the demographic bonus.

Even though the economy of Indonesia is under pressure, but according to the Statistics Indonesia (BPS), in the first quarter (Q1)-2020, Indonesia's GDP expanded by 2.97 percent year-on-year (y/y). However, the Asian Development Bank forecast for Indonesia and Thailand will be gloomy (minus) for growth compared to Vietnam, see Figure 7 below.

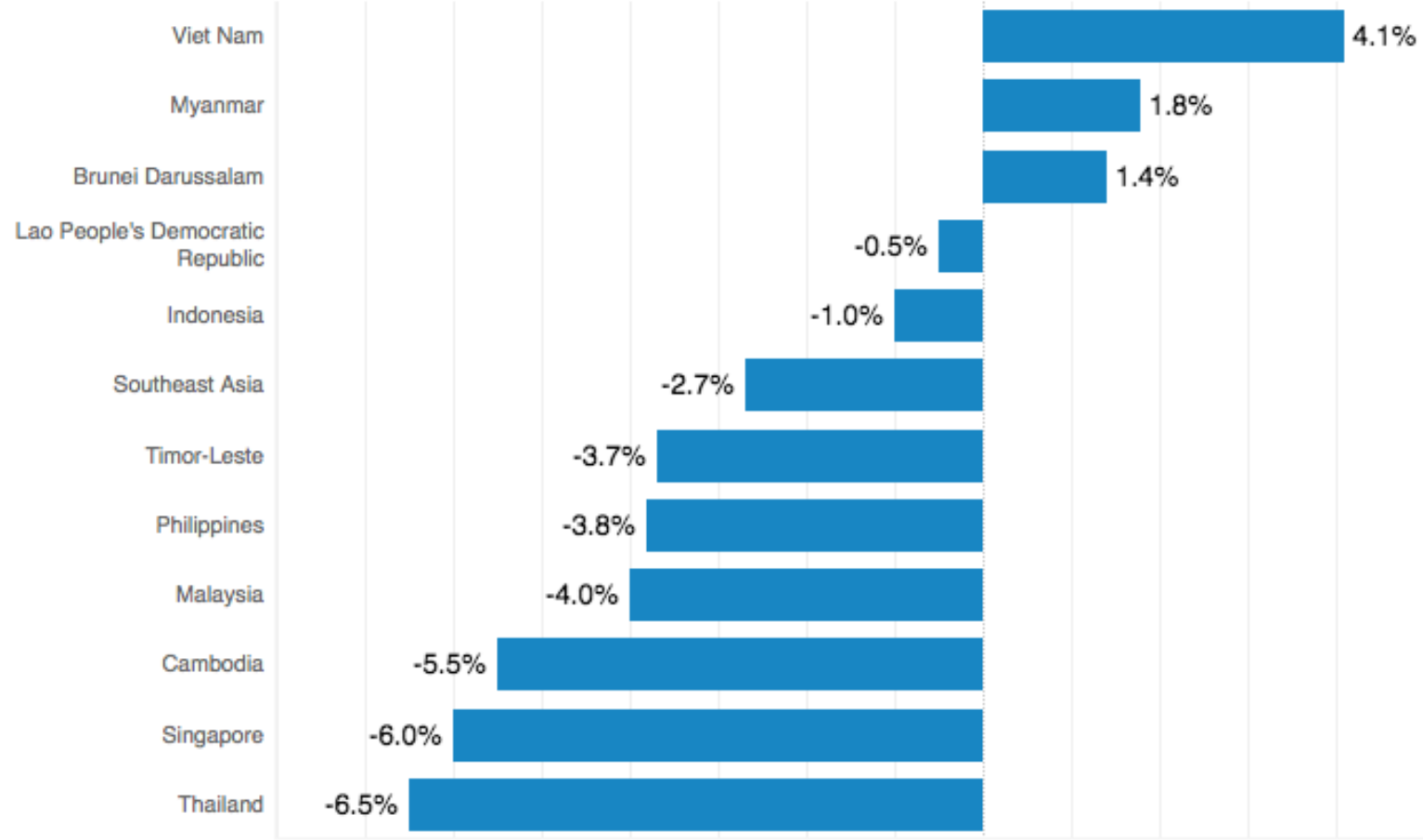

Figure 7: GDP Growth Rate, 2020 Forecast (\% per year)

Source: ADB (2020) 
Economic Stimulus, Thailand's strategy with the first package, valued at 100 billion baht (3.2 billion), also focused on supporting businesses in the form of low-interest loans, deductions in withholding tax, and VAT refunds. On March 24, 2020, the Thai government issued its second stimulus worth 117 billion baht (US\$3.56 billion) (Medina, 2020). Thailand plans to new borrowing of 1 trillion baht (the US $\$ 30,6$ billion) for its latest stimulus package for the economic impact of COVID-19 (Yuvejwattana et al., 2020).

Meanwhile, Indonesia prepares 405 trillion Rupiah (USD 26.5 billion) for a stimulus package by government regulation through the law (Perppu) No 1/2020 to legitimize much more state spending and financial relief on March 31, 2020 (International Science Council, 2020). On the other hand, Vietnam's economic stimulus measures through a draft decree to increase the cap of deductible interest expenses under Clause 3 Article 8 of Decree 20/2017/ND-CP and a draft decree on invoicing by The Ministry of Finance (MoF) (KPMG, 2020). A VND 27 trillion stimulus package released in March, targeting households and small businesses, also helped shore up demand (Delteil, Francois, \& Nguyen, 2020).

\section{Non-Economic Factor: Quality of Health and Public Health System}

Quality of health, Countries that have successfully managed the outbreak tend to be healthier than those that have not. According to Dr. Bushra Mina's recent commentary published in Lancet, obesity and heart disease are among the most significant risk factors for COVID-19 mortality (Halpin, Faner, Sibila, Badia, \& Agusti, 2020). Obesity is rising fast in Southeast Asia, putting a strain on healthcare systems and government budgets. According to a recent report on obesity from Fitch Solutions Macro Research, Vietnam, Thailand, Singapore, the Philippines, Malaysia, and Indonesia have seen a rise in the number of obese adults.

The report recorded Vietnam as having the highest growth for obesity in ASEAN between 2010 and 2014. In five years, Vietnam's obesity rate increased to 38 percent, whereas Indonesia was at 33 percent and Thailand 27 percent (Jamrisko, 2019).

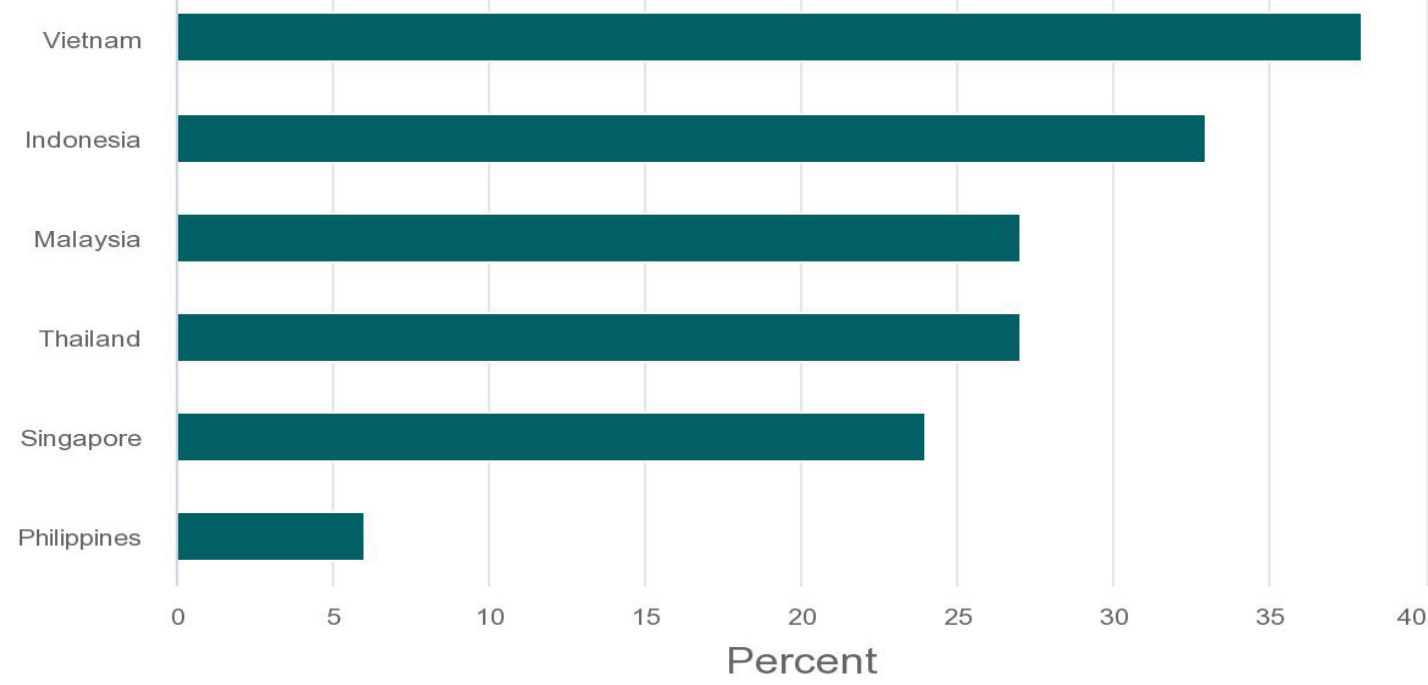

Figure 8: Surge in Obesity in Southeast Asia 2010-14

Source: Jamrisko (2019)

However, Figure 9 below shows that Vietnam had the lowest rate of obese people in 2014 with only 3.6 percent compared to 5.7 percent in Indonesia and 8.5 percent in Thailand (Jamrisko, 2019). According to the Fitch report, the improving economic standards in the region have brought about lifestyle changes, which have led to a shift to more unhealthy diets. 
Food of low nutritional value is more easily and widely available due to its low cost and the introduction and adoption of Western dietary habits (Saigoneer, 2019).

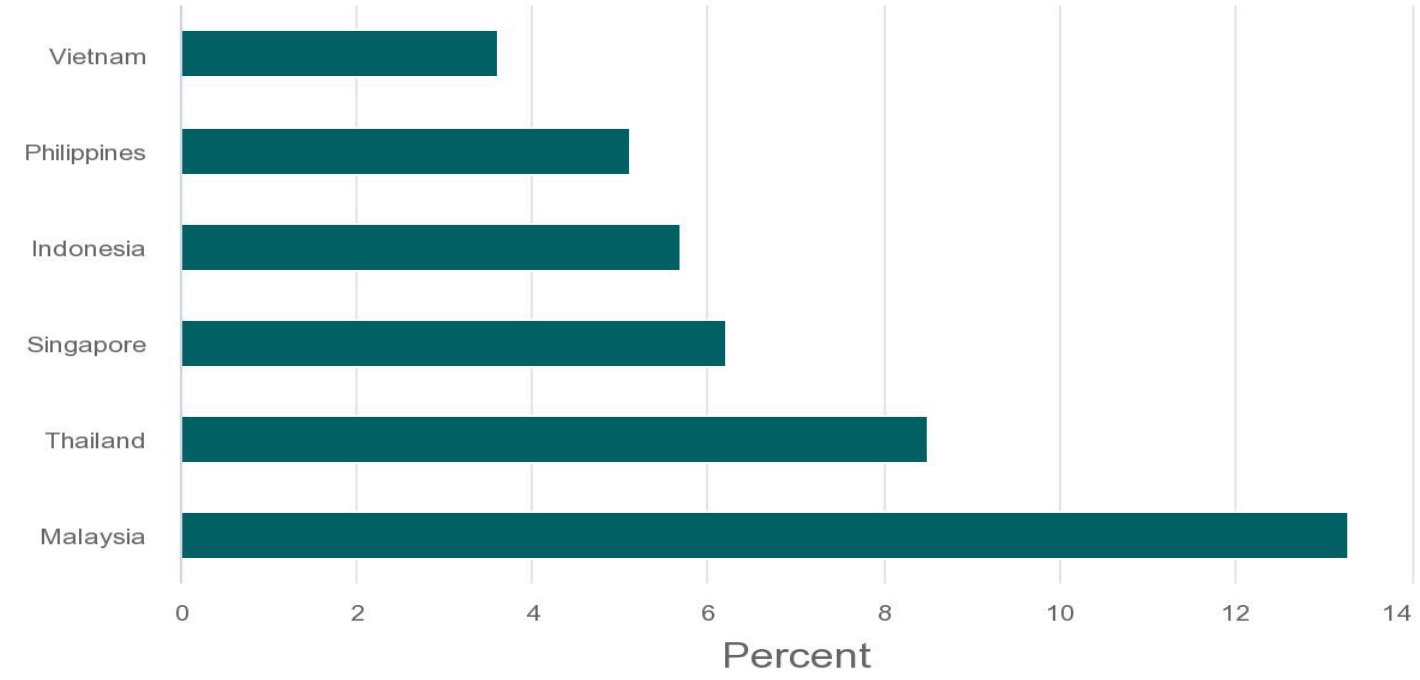

Figure 9: Rate of Obese Adults Per Population in Southeast Asia, 2014

Source: Jamrisko (2019)

In short, prosperous countries have fewer preexisting conditions known to make it more difficult to fight off the virus. Prof. Barry Popkin, a nutrition professor at the University of North Carolina at Chapel Hill School of Public Health in the US, says obesity makes the immune system (Boseley, 2020). Furthermore, Dr. Amir Khan, a doctor in United Kingdom National Health Service, stated that the imbalance in the immune system and chronic inflammation of normal tissue had put people with obesity at increased risk of complications of infections and higher rates of chronic diseases generally, especially COVID-19 (Khan, 2020).

Quality of the public health system, the strength of a country's public health system since day one, is a huge determinant of how well it can handle a pandemic. Following the lessons learned from the past financial crisis, most Southeast Asia countries have strengthened their social protection mechanisms and essential health services. Throughout the region, many innovative pro-poor financing schemes were implemented, such as the Health Card and 30-baht Schemes in Thailand, the Health Fund for the Poor in Vietnam, and BPJS and JKN: The Indonesian National Health Insurance (Hashim et al., 2012).

Despite the highest number of obesity growth, Vietnamese officials have learned lessons from past experiences to pursue a containment strategy involving mass quarantine and rapid contact tracing of coronavirus cases. In the past, the outbreaks of infectious diseases, including SARS in 2003 and periodic flare-ups of swine flu, caused by the H1N1 virus strain. Vietnam experienced an $\mathrm{H} 1 \mathrm{~N} 1$ pandemic in 2009, with over 9,000 cases of people contracting the disease and nearly 20 deaths within four months of the year (Xinhua, 2018).

In response COVID-19 pandemic, the government created the National Steering Committee on COVID-19 Prevention and Control, headed by Deputy Prime Minister Vu Duc Dam, to coordinate the national response. It disseminated information to the public in an uncharacteristically transparent way through daily text messages sent to all mobile network subscribers, frequent articles in state media outlets, banners hung on city streets, and a dedicated COVID-19 website built by the Ministry of Health (M. Vu \& Tran, 2020). The effort was made from the government estimated the budgetary cost of fighting the pandemic at about 0.2 percent of GDP, with about 60 percent spent on equipment, and the rest on containment ac- 
Wicaksono, R. M. T. I Economic Determinants of Growth Acceleration During Covid-19 Pandemic: A Comparative Study Between IndoneA. D., et al. sia, Thailand, and Vietnam

tivities (Dabla-Norris, Gulde-Wolf, \& Painchaud, 2020). Meanwhile, the situations were totally different compare to Indonesia and Thailand.

Thailand's health care system, widely regarded as among the best in Southeast Asia, is now bringing all of its talent and resources to bear to control the outbreak. It is doing so hand-in-hand with experts from the U.S. government and Village Health Volunteers (VHVs). First, it's about 20 percent of the personnel in U.S. Mission Thailand - one of the world's largest embassies - work on health issues with our Thai partners. The U.S. Centers for Disease Control and Prevention (CDC), which has its largest overseas office right here in Bangkok, has four decades of partnership and is co-located with the Thai Ministry of Public Health (MOPH). It has provided over $\$ 133$ million to $\mathrm{MOPH}$ and the Bangkok Metropolitan Administration to support various public health programs related to HIV/AIDS, pandemic influenza, and other infectious diseases (DeSombre, 2020).

Second, in March and April, Thailand was on a partial or "soft" lockdown. The role of village health volunteers (VHVs) in flattening the spread of COVID-19 at the community level. They monitored people's movement in and out of their villages, conducted home visits to check temperature, shared health information about COVID-19 and how to prevent it, recorded household health information, and reported their data to the provincial health office and then the central government afterward. There were over a million VHVs across the country, in addition to more than 15,000 public health volunteers in Bangkok (Bello, 2020).

In fact, Thailand ranked an impressive 6th in the 2019 Global Health Security Index and topped the rankings in Asia. It scored second highest for its health system, third on disease prevention and fifth on rapid response. Therefore, any suspected of having been infected by the novel coronavirus are quickly quarantined and treated, meaning health authorities have been able to efficiently curb the contagion (Thai PBS World, 2020). True, Vietnam has a better record than Thailand, with the first recording 441 infections and seven deaths and the second 327 cases and no fatalities. However, Thailand's record is nothing to sneeze at: 3,083 infections and 57 deaths, with a 96 percent recovery rate (Bello, 2020).

Even the action has been inspired the other countries such as Indonesia. On March 6, officials from the Indonesian Ministry of Health (MoH) visited Thailand's Ministry of Public Health (MOPH) in Bangkok with the support of WHO to observe and discuss effective response activities against the COVID-19 outbreak (WHO, 2020a). Based on the learning's and observations of the visit, some key observations noted during the visit included the capacity to conduct laboratory testing is strengthened through a logistics procurement system that supports a network of laboratories at the national and regional levels, including the utilization of university laboratories.

Countries that plan for and invest in preparedness fare better than those that do not. Vietnam and Thailand were prepared, largely because of their experiences with previous pandemic. Meanwhile, Indonesia itself is considered not yet advanced in public health system. Even before the COVID-19 outbreak in Indonesia, capacity constraints have been an issue in Indonesia. According to figures provided by the Ministry of Health in January 2020, Indonesia currently has only about 321,544 hospital beds to serve a population of about 270 million people (Indonesia Investments, 2020). This explains about 1.2 hospital beds per 1,000 population (see Figure 10), significantly lower than neighbouring economies such as Malaysia, Thailand, and Vietnam. Similarly, the ratio of physicians to population stands at only 0.38 physicians per 1,000 populations - less than half the number for Vietnam and Thailand and only about a quarter of that for Malaysia and Philippines (see Figure 10). 

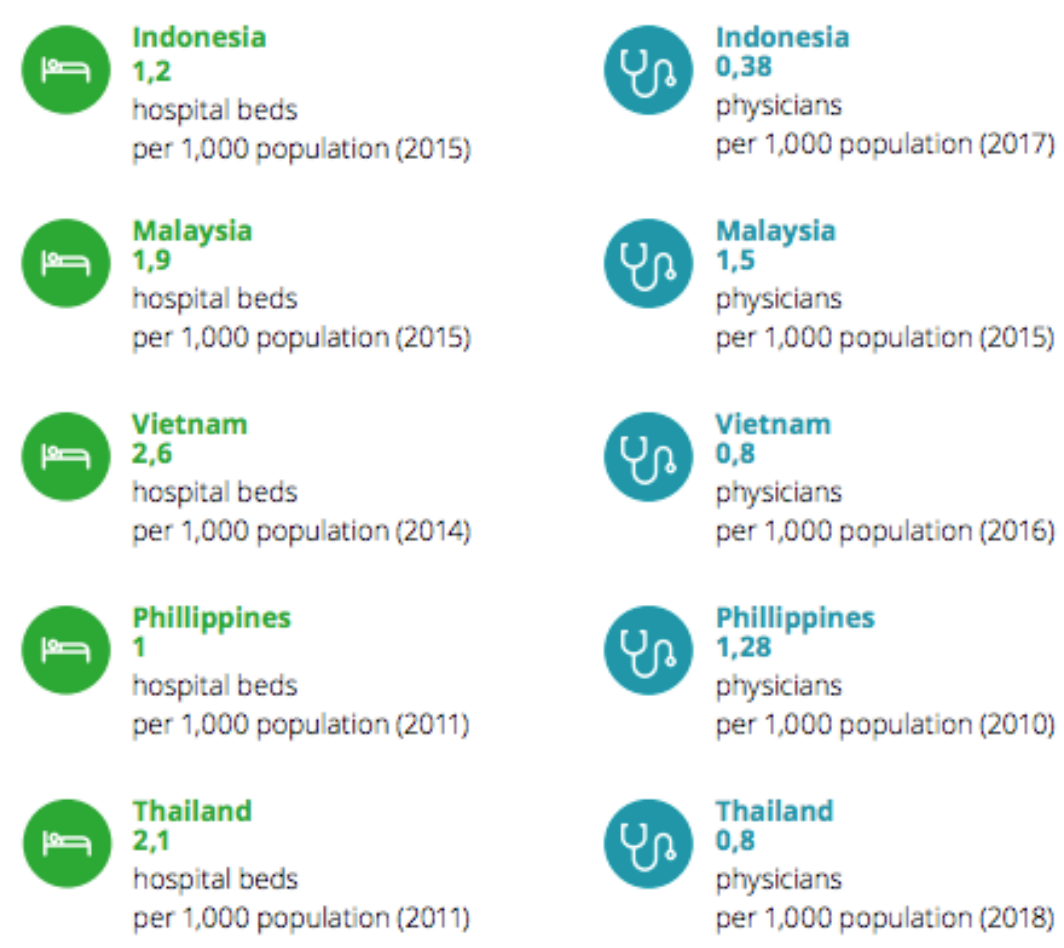

Figure 10: Ratio of hospital beds to population and Ratio of physicians to population

Source: World Bank (2020)

According to Deloitte, there is three key aspects of Indonesia's health care capacity constraints have been identified (Deloitte, 2020): First, shortage of manpower and facilities. Even with the designation of 132 hospitals as COVID-19 referral hospitals across Indonesia's 34 provinces, Indonesia still has one of the lowest testing rates in the world (Cahya, 2020). Second, Lack of protective equipment. The lack of PPE also puts health care workers at risk. As of 19 April 2020, 29 physicians have died since succumbed to COVID-19. Two primary causes of their deaths have been identified: the lack of appropriate PPE, and dishonest disclosures by patients about their medical and travel histories (Pusparisa, 2020).

The last is operational-funding issues. The 14-day claim period, including a 7-day verification period required by BPJS Kesehatan, has been considered too lengthy by the Indonesian Health Law Society (MHKI). It may result in hospitals facing business continuity issues if they run out of operational funding (Pranita, 2020). This situation implies that Indonesia is likely to have a far higher number of COVID-19 cases than it has reported: estimates suggest that only about $21 \%$ of the overall population is reportedly covered by surveillance and testing, with about $15 \%$ of them eventually testing positive for COVID-19 (Jayani, 2020).

\section{Non-Economic Factor: Culture and Social Cohesion}

According to the UN definition, a "cohesive society is one where all groups have a sense of belonging, participation, recognition, and legitimacy". Culture, and cultural heritage, in particular, is fundamental to ensuring inclusive and cohesive societies, as it strengthens identities and creates a sense of rootedness and belonging, in particular for minorities (UNESCO, 2013). Organizations that elevate the good of the whole over individuals' preferences tend to have a greater degree of social cohesion and compliance with rules designed to protect the public in a health crisis (Flournoy \& Morell, 2020).

From an early stage, Vietnam's strategies are full-quarantine and lockdown, communications about the virus, transparent data from the government, and economic anticipation. On February 1, the Vietnam initiatives to tackle the spread of COVID-19 by suspended all flights to and from China. Start to keep schools closed after the lunar New Year break. Two weeks later, 
Wicaksono, R. M. T. I Economic Determinants of Growth Acceleration During Covid-19 Pandemic: A Comparative Study Between IndoneA. D., et al. sia, Thailand, and Vietnam

they imposed a 21-day quarantine in Vinh Phuc province, north of Hanoi. That decision was sparked by concerns over the health status of migrant workers returning from Wuhan, China, where the virus originated (Financial Times, 2020b).

Moreover, Vietnam's whole-of-society mobilization is fighting the pandemic. The government policy on COVID-19 has strengthened Vietnam's social capabilities and boosted digitalization, and committed to transparency through clear communication and regular updates for the public, including tracing apps and leadership messaging, to win social trust and dispel misinformation (Penh, 2020). Even Vietnam could locally develop COVID-19 test kits, with Vietnam even starting to export its own. Given the importance of extensive testing for early containment of the coronavirus spread, both countries should support other ASEAN members in this respect (VOA News, 2020).

Thailand's tentative success could also owe in part to culture, and cohesive social, as Thais traditionally greet without touching through prayer-like, palm-pressed wais. A Buddhism-inspired reticence witnessed on often eerily silent public transit buses and trains have also arguably helped keep aspirated viral contagion out of the air. More clinically, Thailand's universal public health care system with low-cost medical treatment available nearly nationwide, including village-level rural health volunteers who, even in non-pandemic times, have their fingers on the health pulse of local communities (Crispin, 2020b).

In Indonesia, President Joko Widodo announced a confirmed first case of coronavirus on March 2, 2020. Detailed analyses on COVID-19 response in Indonesia have been recently published by Djalante et al.. They found out several vital measures have been issued to respond to the coronavirus cases in Indonesia, including the Taskforce's establishment for the acceleration of COVID-19 on March 13, 2020. The government also imposed Large scale social restriction (PSBB) was to accelerate COVID-19 eradication on March 30, 2020 (Djalante, Shaw, \& DeWit, 2020).

As the largest Muslim globally, The Minister of Health, Terawan Agus Putranto, issued Minister of Health Regulation (Permekes) No. 9 of 2020 concerning Large-Scale Social Limitation Guidelines (PSBB), which assist in licensing religious activities, including in places of worship. This regulation is stipulated in Article 13 of Health Regulation 1 or 1 letter b, which mentions religious activities restrictions. The intended rule is carried out in religious activities at home and attended by limited families by keeping everyone away (Dianka, 2020). That decision was sparked by concerns over mass religious activities, especially during Friday Prayer and Eid celebration.

In some areas that implement large-scale social restrictions (PSBB), such as the capital city (Jakarta), it positively impacts the economy. The calculation of the scenario so that the results gained that economic activity does not stop completely. The estimation was about $75 \%$ controlled for 14 days in the worst scenario, thus having an implication of $-2.78 \%$ against gross Regional domestic product (PDRB) and a decrease in household income of $-2.77 \%$ (Putri, 2020).

\section{Non-Economic Factor: Political and Administrative}

Critical decision-making, Gary Klein describes the Recognition-Primed (or intuitive) decision-making model in his books titled "Sources of Power" and "Intuition at Work" (Klein, 1999). This model assumes experience is the primary source of wisdom in decision-making and results from many observations and studies of real-life cases of people making time-critical decisions in the real world rather than in laboratory conditions. It generally applies to crises where time is minimal, such as an emergency room or firefighting, rather than situations where time is not limited and careful consideration is possible (Ogilvie \& Hauge, 1998). 
Vietnamese leadership began waging war on COVID-19 with early as a decisive action. As soon as the first cases were detected, the government recognized COVID-19 as a significant threat and took precautionary measures even before WHO's recommendation. Besides controlling the border, the government issued Resolution No. 42/NQ-CP (Resolution 42) to help individuals and businesses affected by the COVID-19 pandemic on April 9 (Thu Vien Phap Luat, 2020 b). The Resolution consists of a financial package for those affected by the pandemic and targets six categories of individuals and businesses, including Impacted employees, Impacted employers, Household businesses (with revenue under US\$4,265 (100 million VND) a year), People with meritorious service to the country, Poor and near-poor households; and Social protection beneficiaries (Shira, 2020). Through the Vietnam Bank for Social Policies (VBSP) as a government policy bank, which implements preferential credit policies for the poor and other policy beneficiaries.

Moreover, according to Directive 11/CT-TTG, the government suspends social insurance payments dated March 4, 2020. the Prime Minister requested the Vietnam Social Insurance to assume the primary responsibility and coordinate with the concerned agencies to guide the suspension of payment of social insurance for those affected by the COVID-19 epidemic until the end of June or December 2020 without interest charge for late payment. Vietnam Social Insurance is drafting an official ruling on this issue (Thu Vien Phap Luat, 2020a).

In Thailand, almost 20 million people have registered for government financial aid. This program intends to help people who are severely affected by the outbreak. Specifically, those who lost their jobs were suspended from work and whose businesses have been closed on government orders. As of early May, it was recorded about 13.4 million people have passed the qualification screening and are about to receive a subsidy of 5,000 baht/month. Another scheme initiated by the Thai government is also intended to give 10 million farmers (Languepin, 2020).

In contrast, in Indonesia, the Indonesian government has launched social aid disbursement "Direct-Cash-Assistance" (Bantuan Langsung Tunai) amidst the COVID-19 crisis. However, this program has been criticized for inaccuracy in distributing aid to the intended beneficiaries (Gorbiano, 2020a). The government's unpreparedness also exposes the lousy governance due to a lack of reliable data for targeted recipients and a lack of coordination between regional and central governments (Gorbiano, 2020b). Another criticism has pointed out the pre-employment (Prakerja) program launched by the Indonesian government in early May has received criticism (Rahman, 2020a). The critics against the pre-employment program emphasized that the scheme does not align with the crisis's priority (Virgil, Selo, \& Angdreas, 2020). These criticisms also underline that people who have lost their jobs due to the pandemic should be given direct cash assistance instead of online classes and skills training, which could easily find freely in other learning platforms.

Considering the entire country, according to Michèle Flournoy, countries that have applied policies nationwide or thought through the implications that regional policies could have for the whole of the country have done better than those that have not done so (Flournoy \& Morell, 2020). According to the Head of the National Committee for Avian Flu Control and Pandemic Preparedness in Indonesia, Bayu Krishnamurthi, the terms lockdown and community quarantine are synonymous. Both are used interchangeably to refer to a type of quarantine. All citizens in a particular region are prohibited from going and come to the territory without official permission from authorities (Fachriansyah \& Cahya, 2020). With about 70 million people, Southeast Asia was the first country outside China to report a case of coronavirus; on January 13 (Nytimes, 2020), Vietnam, Thailand, and Indonesia implemented mass quarantines in suspected risky spots based on evolving epidemiological evidence over time.

Since February 2020, Vietnam entered a nationwide lockdown in Son Loi Commune (Vinh Phuc Province) (Onishi, 2020). Initially, they set the lockdown for 15 days, but it extended to 21 days in 28 out of 63 provinces (K. Vu, Nguyen, \& Pearson, 2020). Even before the first cases 
Wicaksono, R. M. T. I Economic Determinants of Growth Acceleration During Covid-19 Pandemic: A Comparative Study Between IndoneA. D., et al. sia, Thailand, and Vietnam

in Vietnam were confirmed, Vietnam took the first of many steps to implement closures and limit mobility for citizens and international travelers. In early February, Vietnam began implementing international arrivals from COVID-19 affected countries in large government-run quarantine centers for 14 days.

Vietnam began using Vietnamese arrivals from China on February 4 and expanded the practice to Vietnamese arrivals from South Korea on March 1 and, finally, for all international arrivals beginning March 20-22. International flights were also diverted away from airports still used for domestic travel (Todd Pollac, 2020). Deputy Minister of Health Do Xuan Tuyen said that regarding the disease, the Government and the Ministry of Health had directed the establishment of inspection teams at border gates and localities. The Ministry of Health has provided instructions on disease prevention and treatment (Trang, 2020).

Meanwhile, Thailand was the first country outside that reported the first case of coronavirus in Southeast Asia. On January 13, there has been a relative success story containing it, with just 3,135 confirmed cases and 58 fatalities. Some 2,987 patients have recovered (Chinadaily, 2020). On March 26, to stop the spread of the novel coronavirus, Thailand announced a lockdown. However, Thailand becomes the latest country to go into a broad lockdown when a state of emergency is enforced to fight the spread of novel coronavirus. Prime Minister Prayuth Chan-Ocha's policy on the closed border for foreign visitors, social gatherings banned, domestic travel restricted and shut all but essential shops at the end of April (Thanthong-Knight, 2020). As a result, Thailand lifted a nationwide curfew after more than two months. It allowed restaurants to resume selling alcohol as the coronavirus crisis eased, with 21 days since a recorded local transmission case on June 2020 (The Jakarta Post, 2020).

Indonesian President Joko Widodo has argued that a complete lockdown's economic and social cost is unfeasible compared to Indonesia. The Ministry of Law and Human Rights No 11/2020 on temporary travel bans for foreigners who enter the territory on April 2, 2020 (International Science Council, 2020). Still, these local lockdowns can't offset the economic fallout from the pandemic.

Many Indonesians have expressed frustration with the government for failing to deliver promised aid packages (Varagur, 2020).

Indonesia adopted the partial lockdown requires offices, schools, places of worship, and public spaces to close. Local administrations imposing the PSBB can limit transportation capacity within a region but are not given authority to close inter-regional transportation services (Sutrisno, 2020). According to Achmad Sukarno, a senior analyst at Control Risks, implementing stricter social distancing in Jakarta was not effective as many businesses are allowed to remain open. If it wants to be effective, it needs to have vigorous enforcement (Listiyorini \& Suhartono, 2020).

Leadership, Leaders who act decisively and early, demonstrate competence in making tough decisions, communicate the facts clearly and consistently, and show empathy for those affected navigate crises far better than those who do not (Flournoy \& Morell, 2020). In many countries, including Indonesia, Thailand, and Vietnam, the governments set restrictions that restrict proximity between people, travel restrictions, school closures, and workplace closures.

Oxford's public policy school, the Blavatnik School of Government, maintains the policy response data presented in Table 2 below. They publish it as the Coronavirus Government Response Tracker (OxCGRT). The Oxford COVID-19 Government Response Tracker (OxCGRT) systematically collects information on several different common policy responses that governments have taken to respond to the pandemic on nine indicators, such as school closures and travel restrictions (Blavatnik School of Government, 2020). The researchers also calculate a summary measure of the response metrics called the Government Stringency Index.

The Government Stringency Index are school closures, workplace closures, public 
events, public gatherings, public transport, stay-at-home requirements, general information campaigns, restrictions on internal movements, and international travel controls (Blavatnik School of Government, 2020).

Table 2: The Government Response Stringency on COVID-19

\begin{tabular}{cccc}
\hline Timeline & Indonesia & Thailand & Vietnam \\
\hline January 21, 2020 & 8.33 & 0.00 & 0.00 \\
\hline February 21, 2020 & 47.22 & 0.00 & 28.7 \\
\hline March 21, 2020 & 43.52 & 52.31 & 47.22 \\
\hline April 21, 2020 & 71.76 & 81.02 & 86.57 \\
\hline May 21, 2020 & 71.76 & 72.22 & 65.74 \\
\hline June 21, 2020 & 68.06 & 56.48 & 54.63 \\
\hline Source: Our World in Data $(2020)$ & & &
\end{tabular}

We rescaled to a value from 0 to 100 , the highest, which is the strictest response with a value of 100 . A higher score means a country has stringent measures. Countries worst-hit by the epidemic have a lower score. The study result that, even though in July 2020, Indonesia leads the position compare to Vietnam and Thailand. However, the only one who reaches out with a value above 85 is Vietnam. The importance of implementing measures is on time; thus, here's (Figure 11) the comparison of the total number of confirmed COVID-19 cases as of July 14, 2020.

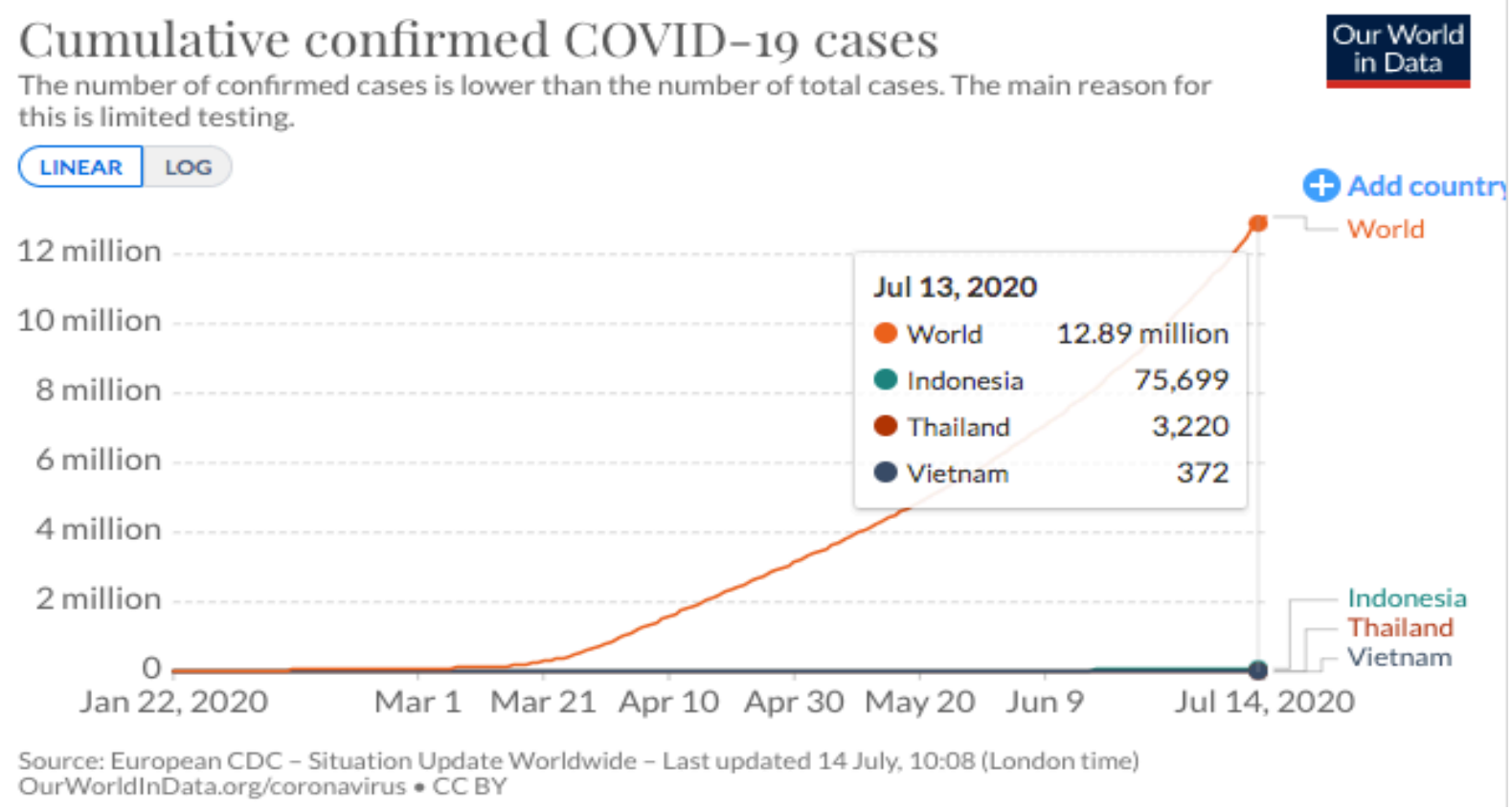

Figure 11: The Comparison of Cumulative Confirmed COVID-19 Cases as of July 14, 2020

Source : European CDC (2020)

While leaders in many countries downplayed the threat of COVID-19, the Vietnamese government communicated in clear, strong terms about the dangers of the illness even before the first case was reported. On May 18-19, 2020. Prime Minister Nguyen Xuan Phuc has been recently shared the country's experience. Vietnam's timely and evidence-based response has led to tremendous success in containing the COVID-19 outbreak, with just over 300 positive cases and no deaths. At the 73rd World Health Assembly, The enviable success story has been applauded across the globe. 
Wicaksono, R. M. T. I Economic Determinants of Growth Acceleration During Covid-19 Pandemic: A Comparative Study Between IndoneA. D., et al. sia, Thailand, and Vietnam

One of the successful measures was health crisis management. The Ministry of Health first warned citizens of the threat on January 9. Since then, the government has communicated frequently with the public. Adding a short prevention statement to every phone call placed in the country, texting people directly (Chambers et al., 2020). The government taking advantage of Vietnam's high use of social media with over 64 million active Facebook users. Other than that, 80 percent of smartphone users in Vietnam have the local social media app named Zalo (La et al., 2020). Throughout these communications, the government always used the motto: "Fighting the epidemic is like fighting against the enemy." (M. Vu \& Tran, 2020). This messaging engendered a community spirit in which citizens felt inspired to do their part, whether wearing a mask in public or enduring weeks of quarantine.

On the other hand, Thailand Prime Minister Prayut Chan-O'Shea's government has imposed a state of emergency through April under which mass gatherings are banned. The lockdown gives the former army chief a window to burnish his leadership credentials to defeat the outbreak and alleviate its social toll. Prayut has power over government ministries and has made the military the primary security arm for the recently set up COVID-19 response center (The Japan Times, 2020). However, the big picture point is that Prayut's government has freed up at least $\$ 60$ billion for discretionary crisis relief distribution (Crispin, 2020a).

At the 36th ASEAN Summit, when Prime Minister Nguyen Xuan Phuc of Vietnam, which is the current chair of ASEAN, warned that the virus pandemic could cause an economic calamity as it has swept away years of financial gains in the region. Thailand Prime Minister Prayut Chan-o-cha responded to called on ASEAN members to collaborate over public health to reopen intra-regional travel as part of post-COVID 19 measures to restore the regional economy (Bangkok Post, 2020). Meanwhile, Indonesian President Joko "Jokowi" Widodo proposes the regional travel corridor arrangement as a crucial measure to accelerate economic recovery (Septiari, 2020).

In this case, as the highest cumulative total of confirmed cases compared to Thailand and Vietnam, Indonesia should make controlling the epidemic a priority rather than focusing on bringing the economy back to normal. Meanwhile, other ASEAN states such as Vietnam have all reported zero cases over the past few weeks. Moreover, The President of Jokowi decides whether to declare states of emergency up to the individual regional heads. Meanwhile, World Health Organization director-general Tedros Adhanom Ghebreyesus urged Jokowi to declare a national state of emergency to scale up its emergency response for containing the COVID-19 outbreak (Cahya, 2020).

Table 3: GDP Growth and Confirmed Cases During COVID-19 Pandemic

\begin{tabular}{ccc}
\hline $\begin{array}{c}\text { Real GDP Growth (Annual per- } \\
\text { cent change - April 2020) }\end{array}$ & $\begin{array}{c}\text { Confirmed Cases - Weekly } \\
\text { confirmed COVID-19 cases } \\
\text { as July 18, 2020² }\end{array}$ & $\begin{array}{c}\text { The total number of } \\
\text { confirmed deaths causes } \\
\text { COVID-19 as July 18, 2020 }\end{array}$ \\
\hline 0.5 percent (\%) & -6.7 percent (\%) & 2.7 percent (\%) \\
\hline 10,783 cases & 30 cases & 3 cases \\
\hline 3,957 deaths & 58 deaths & 0 deaths \\
\hline
\end{tabular}

Source: (IMF, 2020; Ritchie et al., 2020a;Ritchie et al., 2020b)

The virus that causes COVID-19 Pandemic is a formidable foe. But some countries have shown that we can beat it. Indonesia should learn from experience and follow Thailand and Vietnam's lead regarding measuring the quality of health and public health system, considering the lockdown policy and critical decision-making by the government. The outcome of confirmed cases and death causes by COVID-19 in Vietnam and Thailand could categorize as low compare to Indonesia. 
However, based on GDP growth, Indonesia still grows positively compare to Thailand, but not to Vietnam. Vietnam successfully limited the spread of COVID-19 so far, while the real GDP growth with 2.7 percent in April 2020.

\section{Conclusion \& Suggestion}

Since the first COVID-19 case was confirmed in Thailand in mid-January, Indonesia, Thailand, and Vietnam have progressed differently in their COVID-19 responses. Some countries succeed at containing the virus, and others are still grappling with high rates of infection. These results strengthen the case for active government action to support people most likely to be affected by the continued economic disruption, with or without active government lockdowns. Vietnam's successful management of COVID-19 has also been extended to the economy and is projected to be one of the worlds' fastest-growing countries in 2020.

Looking at the structure of international trade and services in Vietnam, the Smith-Ricardo model is mostly confirmed. A large proportion of Indonesia and Vietnam's exports originate from absolute advantages. This is the case for natural resource exports like crude oil and minerals and most agricultural exports whose competitiveness largely depends on the climate, both in Indonesia and Vietnam.

Indonesia itself is considered not yet advanced in protecting the business world from the adverse effects of the Pandemic. It can be seen from the amount of the budget for funding stimulus programs for domestic industries, which are still relatively small, which is reflected in government decision-making. Meanwhile, Vietnam and Thailand are considered more advanced in handling the COVID-19 Pandemic. Based on the low level of transmission and the number of fatalities exposed to the Pandemic.

The economic determinants of growth acceleration that dominant were natural resources, investment, FDI, and population growth. However, during COVID-19, the most important were non-economic factors such as quality of health and public health system that affected the number of cases and deaths. Culture and social cohesion affected the society to support the government. Political and administrative lead to leader credibility as a result of its organizational ability to handle the COVID-19 Pandemic.

In the end, Thailand and Vietnam strategies that are full-quarantine and complete lockdown could be the lessons to respond against the COVID-19 Pandemic or even the anticipation plans in the future for Indonesia. Thus, referring to the examples made by Thailand and Vietnam, Indonesia needs to take lessons on how to formulate policies that are not only on target but also on priority. The first step that can take is to be aware of the severe effects of this Pandemic. The government should then realize that saving economic interests over public health would only bring even more significant and protracted losses later.

For a suggestion, enhancing the pandemic responses, pandemic outbreaks such as COVID19 will continue to occur, but where and how severe the next pandemic will be, no one can predict. The COVID-19 experience highlighted the need for the region to have a holistic and comprehensive response mechanism to the outbreak of a pandemic, going beyond the health sector response and considering the broad implications of a pandemic, including the economy and livelihood of the people.

Prioritize the quality and public health system, crucially; those designing these public-health countermeasures must recognize that there will be direct and indirect health effects, affecting, in particular, those living alone and also long-term consequences for the economy. Thus, the strength of the economic recovery will depend on effective policy response, particularly adequate support to vulnerable households and firms. 
Wicaksono, R. M. T. | Economic Determinants of Growth Acceleration During Covid-19 Pandemic: A Comparative Study Between IndoneA. D., et al. sia, Thailand, and Vietnam

\section{References}

Abramson, P. R., Harrison, L. E., \& Huntington, S. P. (2001). Culture Matters: How Values Shape Human Progress. Contemporary Sociology, 30(6), 627. https://doi.org/10.2307/3089031

ADB. (2017). Asian Development Outlook (ADO) 2017: Transcending the Middle-Income Challenge. Retrieved July 18, 2020, from https://www.adb.org/publications/asian-development-outlook-2017-middle-income-challenge

Akhlas, A. W. (2020). Clouds thicken over Indonesia's economic growth as uncertainties persist. Retrieved July 5, 2020, from https://www.thejakartapost.com/news/2020/06/21/ clouds-thicken-over-indonesias-\%09economic-growth-as-uncertainties-persist.html

Amalia, L. (2007). Ekonomi Internasional (1st ed.). Yogyakarta: Graha Ilmu.

Arsyad, L. (1999). Pengantar perencanaan dan pembangunan ekonomi daerah. Yogyakarta: BPFE.

Arunmas, P. (2020). Exports continue monthly decline. Retrieved July 17, 2020, from https:// www.bangkokpost.com/business/1799359/exports-continue-monthly-decline

Asia Funds Managers. (2020). Indonesia Economy - Tremendous progress over the last two decades. Retrieved July 18, 2020, from https://www.asiafundmanagers.com/int/indonesia-economy-outlook/

Badan Pusat Statistik. (2020). Ekspor Mei 2020 Mencapai US\$10,53 Miliar dan Impor Mei 2020 sebesar US\$8,44 Miliar. Retrieved from https://www.bps.go.id/pressrelease/2020/06/15/1679/ekspor-mei-2020-mencapai-us-10-53-miliar-dan-impor-mei2020-sebesar-us-8-44-miliar.html

Bangkok Post. (2020). PM urges Asean travel relaunch. Retrieved July 14, 2020, from https:// www.bangkokpost.com/thailand/general/1941628/pm-urges-asean-travel-relaunch

Bello, W. (2020). In politically turbulent Thailand, how public health system curbed Covid-19. Retrieved July 12, 2020, from https://www.business-standard.com/article/ international/in-politically-turbulent-thailand-how-public-health-system-curbed-cov id-19-120060400237_1.html

BKPM. (2020a). BKPM Chairman Invites the Provincial Government to Encourage Investment amid the COVID-19 Pandemic. Retrieved July 18, 2020, from https://www.bkpm.go.id/ en/siaran-pers/readmore

BKPM. (2020b). Here are 5 Countries with Biggest Foreign Direct Investment in Indonesia. Retrieved July 18, 2020, from https://www.investindonesia.go.id/en/article-investment/ detail/here-are-5-countries-\%09with-biggest-foreign-direct-investment-in-indonesia

BKPM. (2020c). SIARAN PERS Investasi Triwulan I Tahun 2020 Naik 8,0\% Mencapai Rp 210,7 Triliun. Retrieved from https://www.bkpm.go.id/images/uploads/file_siaran_pers/Narasi_Press_Release_TW_1_2020_Final.pdf

Blavatnik School of Government. (2020). Coronavirus Government Response Tracker. Retrieved July 14, 2020, from https://www.bsg.ox.ac.uk/research/research-projects/coronavirus-government-response-tracker

Boseley, S. (2020). Obesity and coronavirus: how can a higher BMI increase your risk? Re- 
trieved July 8, 2020, from https://www.theguardian.com/world/2020/jun/03/obesityand-coronavirus-how-can-a-higher-bmi-increase-your-risk

CABINET SECRETARIAT OF THE REPUBLIC OF INDONESIA. (2020). WHO, IMF Predict Indonesia's Economy Will Still Grow Amidst COVID-19 Pandemic. Retrieved July 15, 2020, from https://setkab.go.id/en/who-imf-predict-indonesias-economy-will-still-grow-amidstcovid-19-pandemic/

Cahya, G. H. (2020). Stay home, President says. Retrieved July 14, 2020, from https://www. thejakartapost.com/news/2020/03/16/stay-home-president-says.html

Chambers, M., Choisy, M., Day, J., Trinh, D. H. K., Tam, D. T. H., Donovan, J., ... Choisy, M. (2020). The first 100 days of SARS-CoV-2 control in Vietnam. MedRxiv. https://doi. org/10.1101/2020.05.12.20099242

Chinadaily. (2020). Singapore to remove most virus restrictions from Friday. Retrieved July 13, 2020, from https://www.chinadailyasia.com/article/133734

Crispin, S. W. (2020a). Covid-19 gives Prayut new political life in Thailand. Retrieved July 14, 2020, from https://asiatimes.com/2020/07/covid-19-gives-prayut-new-political-life-inthailand/

Crispin, S. W. (2020b). Thailand's unsung Covid-19 success story. Retrieved July 13, 2020, from https://asiatimes.com/2020/05/thailands-unsung-covid-19-success-story/

Dabla-Norris, E., Gulde-Wolf, A.-M., \& Painchaud, F. (2020). Vietnam's Success in Containing COVID-19 Offers Roadmap for Other Developing Countries. Retrieved July 8, 2020, from https://www.imf.org/en/News/Articles/2020/06/29/na062920-vietnams-success-incontaining-covid19-offers-roadmap-for-other-developing-countries

Databoks. (2020). Realisasi Investasi Turun 4,3\% pada Kuartal II-2020. Retrieved July 24, 2020, from https://databoks.katadata.co.id/datapublish/2020/07/22/realisasi-investasi-turun-43-pada-kuartal-ii-2020

Deloitte. (2020). Rising to the COVID-19 Health Care Challenge in Indonesia. Retrieved July 12, 2020, from https://www2.deloitte.com/id/en/pages/life-sciences-and-healthcare/ articles/rising-to-covid-19-health-care-challenge-in-indonesia.html

Delteil, B., Francois, M., \& Nguyen, N. (2020). Emerging from the pandemic, Vietnam must position itself for recovery. Retrieved July 18, 2020, from https://www.mckinsey.com/ featured-insights/asia-pacific/emerging-from-the-pandemic-vietnam-must-position-itself-for-recovery\#

Deshmukh, A. (2020). EU - Vietnam Free Trade Agreement: Vietnam's Competitive Gains. Retrieved July 16, 2020, from https://globalriskinsights.com/2020/05/eu-vietnam-freetrade-agreement-vietnams-competitive-gains/

DeSombre, M. G. (2020). Tackling COVID-19: The Latest Challenge for U.S.-Thai Health Cooperation. Retrieved July 12, 2020, from https://th.usembassy.gov/tackling-covid-19-thelatest-challenge-for-u-s-thai-health-cooperation/

Dianka, A. A. (2020). Ini Aturan Pembatasan Kegiatan Ibadah dalam PSBB. Retrieved July 13, 2020, from https://www.trenasia.com/ini-aturan-pembatasan-kegiatan-ibadah-dalam-psbb/ 
Dinh, H. (2020). Vietnam Ratifies Trade Deal With EU in Boost for Economy. Retrieved July 16, 2020, from https://thediplomat.com/2020/06/vietnam-ratifies-trade-deal-with-euin-boost-for-economy/

Djalante, R., Shaw, R., \& DeWit, A. (2020). Building resilience against biological hazards and pandemics: COVID-19 and its implications for the Sendai Framework. Progress in Disaster Science. https://doi.org/10.1016/j.pdisas.2020.100080

Ducharme, J. (2020). World Health Organization Declares COVID-19 a "Pandemic." Here's What That Means. The Time, 7-9. Retrieved from https://time.com/5791661/who-coronavirus-pandemic-declaration

Fachriansyah, R., \& Cahya, G. H. (2020). COVID-19: Does Indonesia need a lockdown? It depends on how you define it. Retrieved July 18, 2020, from https://www.thejakartapost. com/news/2020/03/19/covid-19-does-indonesia-need-a-lockdown-it-depends-on-howyou-define-it.html

Fauz, A. (2009). Sinergi antara Pembangunan Ekonomi dan Pengelolaan Sumber Daya Alam dan Lingkungan. Jurnal Ekonomi Lingkungan, 13(2), 1-15.

Financial Times. (2019). the overwhelming majority (90\%) of the 2.4 billion new members of the middle class. Retrieved July 18, 2020, from https://www.ft.com/content/e3fa475cc2e9-11e8-95b1-d36dfef1b89a

Financial Times. (2020a). Samsung shifts some smartphone production to Vietnam due to coronavirus. Retrieved July 18, 2020, from https://www.ft.com/content/79d80650-5f9d11ea-b0ab-339c2307bcd4

Financial Times. (2020b). Vietnam's coronavirus offensive wins praise for low-cost model. Retrieved July 12, 2020, from https://www.ft.com/content/0cc3c956-6cb2-11ea-89df41bea055720b

Flournoy, M., \& Morell, M. (2020). Opinion: The 6 factors that determine coronavirus containment or devastation. Retrieved July 4, 2020, from https://www.washingtonpost.com/ opinions/2020/04/19/6-factors-that-determine-coronavirus-containment-or-devastation/

Gorbiano, M. I. (2020a). Cash aid disbursement fails to meet Idul Fitri target. Retrieved July 13, 2020, from https://www.thejakartapost.com/news/2020/05/28/cash-aid-disbursementfails-to-meet-idul-fitri-target.html

Gorbiano, M. I. (2020b). COVID-19 crisis exposes holes in social aid disbursement. Retrieved July 13, 2020, from https://www.thejakartapost.com/news/2020/05/19/covid-19-crisisexposes-holes-in-social-aid-disbursement.html

Ha, D. T. (2020). Vietnam's Economy to Grow Fastest in Southeast Asia Despite COVID-19: ADB. Retrieved July 5, 2020, from https://www.vietnam-briefing.com/news/vietnams-economy-grow-fastest-southeastasia-despite-covid-19.html/\#: :text=According to the ADB's Asian,provided the pandemic is contained.

Halpin, D. M. G., Faner, R., Sibila, O., Badia, J. R., \& Agusti, A. (2020). Do chronic respiratory diseases or their treatment affect the risk of SARS-CoV-2 infection? Retrieved July 8, 2020, from https://www.thelancet.com/action/showPdf?pii=S2213-2600\%2820\%2930167-3 
Hashim, J., Chongsuvivatwong, V., Phua, K. H., Pocock, N., Teng, Y. M., Chhem, R. K., ... Lopez, A. (2012). Health and Healthcare Systems in Southeast Asia. Retrieved July 8, 2020, from https://unu.edu/publications/articles/health-and-healthcare-systems-in-southeast-asia. html

Herr, H., Schweisshelm, E., \& Vu, T.-M. (2016). Vietnam in the global economy: development through integration or middle-income trap? Retrieved from https://asia.fes.de/ news/vietnam-in-the-global-economy-development-through-integration-or-middle-income-trap/

Hospita, M. E. (2020). Coronavirus cases in Southeast Asia top 150,000. Retrieved July 4, 2020, from https://www.aa.com.tr/en/asia-pacific/coronavirus-cases-in-southeast-asia-top-150-000/1894835

IMF. (2020). Real GDP growth - Annual percent change. IMF DataMapper.

Indonesia Investments. (2020). Can Indonesia's Healthcare Industry Cope with the Growing Number of COVID-19 Patients? Retrieved July 12, 2020, from https://www.indonesia-investments.com/id/news/todays-headlines/can-indonesia-s-healthcare-industry-copewith-the-growing-number-of-covid-19-patients/item9261

International Science Council. (2020). Indonesia COVID-19 Policy-Making Tracker. Retrieved July 13, 2020, from https://www.ingsa.org/covid/policymaking-tracker/asia/indonesia/

Jamrisko, M. (2019). Obesity Is Climbing Faster in Vietnam Than Anywhere in Southeast Asia. Retrieved July 8, 2020, from https://www.bloomberg.com/news/articles/2019-07-19/ obesity-is-climbing-the-fastest-in-vietnam-in-southeast-asia

Jayani, D. H. (2020). Posisi Kesiapan Indonesia di Dunia Hadapi Ledakan Covid-19. Retrieved July 12, 2020, from https://katadata.co.id/timdatajournalism/analisisdata/5f12687508268/ posisi-kesiapan-indonesia-di-dunia-hadapi-ledakan-covid-19

Jennings, R. (2017). Vietnam Is Losing Economic Ground To China Due To Lack Of HighSkilled Workers. Retrieved July 18, 2020, from https://www.forbes.com/sites/ralphjennings/2017/06/07/vietnam-is-losing-ground-to-china-because-it-lacks-skilled-workers/?sh=3427ebdb6256

Jhingan, M. . (2008). Ekonomi Pembangunan dan Perencanaan. Jakarta: PT Raja Grafindo Persada.

Jong-Wha, L. (2018). Making the most of Asia's aging populations. Retrieved July 18, 2020, from https://theaseanpost.com/article/making-most-asias-aging-populations

Kementerian Keuangan RI. (2020). Menjaga Ekonomi Indonesia Terhadap Dampak Negatif Pandemik COVID-19. Retrieved from https://www.kemenkeu.go.id/publikasi/siaran-pers/ siaran-pers-menjaga-ekonomi-indonesia-terhadap-dampak-negatif-pandemik-covid-19/

Khan, A. (2020). Doctor's Note: Is obesity a risk factor for coronavirus? Retrieved July 8, 2020, from https://www.aljazeera.com/features/2020/5/11/doctors-note-is-obesity-a-riskfactor-for-coronavirus

Klein, G. A. (1999). Sources of Power: How People Make Decisions. MIT Press.

KPMG. (2020). Vietnam Government and institution measures in response to COVID-19. Retrieved July 18, 2020, from https://home.kpmg/xx/en/home/insights/2020/04/viet- 
Wicaksono, R. M. T. | Economic Determinants of Growth Acceleration During Covid-19 Pandemic: A Comparative Study Between IndoneA. D., et al.

nam-government-and-institution-measures-in-response-to-covid.html

Kuncoro. (2006). Ekonomika pembangunan. Teori, masalah, dan kebijakan. Yogyakarta: UPP STIM YKPN.

La, V. P., Pham, T. H., Ho, M. T., Nguyen, M. H., Nguyen, K. L. P., Vuong, T. T., ... Vuong, Q. H. (2020). Policy response, social media and science journalism for the sustainability of the public health system amid the COVID-19 outbreak: The vietnam lessons. Sustainability (Switzerland), 12(7). https://doi.org/10.3390/su12072931

Labovitz, S., Przeworski, A., Teune, H., Holt, R., \& Turner, J. (1971). The Logic of Comparative Social Inquiry. American Sociological Review, 36(2), 329-332. https://doi. org/10.2307/2094059

Landman, T. (2003). Issues and Methods in Comparative Politics: An Introduction. America. Routledge.

Languepin, O. (2020). 23 million Thais to receive 5,000 baht cash subsidy. Retrieved July 13, 2020, from https://www.thailand-business-news.com/economics/79116-23-millionthais-to-receive-5000-baht-cash-subsidy.html

Lee, Y. N. (2020). Southeast Asia could be the next coronavirus hot spot - these charts show why. Retrieved July 4, 2020, from https://www.cnbc.com/2020/04/20/southeast-asiacould-be-the-next-coronavirus-hot-spot-these-charts-show-why.html

Listiyorini, E., \& Suhartono, H. (2020). Indonesia Extends Partial Lockdown in Capital to Curb Virus. Retrieved July 18, 2020, from https://www.bloomberg.com/news/articles/2020-04-22/indonesian-capital-extends-partial-lockdown-to-curb-virus-spread

Macan-Markar, M. (2020). Thailand drums up post-COVID-19 investment in medical supplies. Retrieved July 18, 2020, from https://asia.nikkei.com/Editor-s-Picks/Interview/Thailanddrums-up-post-COVID-19-investment-in-medical-supplies

Mahiddin, F., \& Wirabuana, R. N. (2020). Indonesia: Impact Of COVID-19 Pandemic On Indonesian Oil And Gas Upstream Activities. Retrieved July 15, 2020, from https://www. mondaq.com/operational-impacts-and-strategy/952208/impact-of-covid-19-pandemicon-indonesian-oil-and-gas-upstream-activities

Maliszewska, M., Mattoo, A., \& Mensbrugghe, D. van der. (2020). The Potential Impact of COVID-19 on GDP and Trade: A Preliminary Assessment. Retrieved from https://openknowledge.worldbank.org/bitstream/handle/10986/33605/The-Potential-Impact-ofCOVID-19-on-GDP-and-Trade-A-Preliminary-Assessment.pdf

MARD. (2020). Vietnam's agricultural exports decline in May due to COVID-19. Retrieved July 17, 2020, from https://www.mard.gov.vn/en/Pages/vietnam's-agricultural-exports-decline-in-may-due-to-covid-19.aspx

Medina, A. F. (2020). Thailand Issues Second COVID-19 Stimulus Package. Retrieved July 14, 2020, from https://www.aseanbriefing.com/news/thailand-issues-second-covid-19-stimulus-package/

Menteri Kesehatan RI. (2020). Peraturan Menteri Kesehatan Republik Indonesia Nomor 9 Tahun 2020 Tentang Pedoman Pembatasan Sosial Berskala Besar Dalam Rangka Percepatan Penanganan Corona Virus Disease 2019 (Covid-19). 
Ministry of Planning and Investment Vietnam. (2019). Brief on foreign direct investment of 2019. Retrieved from http://www.mpi.gov.vn/en/Pages/tinbai.aspx?idTin=45020\&idcm=122http://www.mpi.gov.vn/en/Pages/tinbai.aspx?idTin=45020\&idcm=122

Morisset, J. (2020). Vietnam: a bright star in the COVID-19 dark sky. Retrieved July 18, 2020, from https://blogs.worldbank.org/eastasiapacific/vietnam-bright-star-covid-19-dark-sky

Muramatsu, Y., \& Jibiki, K. (2020). Southeast Asia's auto plants limp along at $30 \%$ of capacity. Retrieved July 18, 2020, from https://asia.nikkei.com/Business/Automobiles/SoutheastAsia-s-auto-plants-limp-along-at-30-of-capacity

Nguyen, J. (2020). FDI Data Shows Vietnam's Steady Economic Growth. Retrieved July 19, 2020, from https://www.vietnam-briefing.com/news/fdi-data-shows-vietnams-steadyeconomic-growth.html/

Nguyen, T. (2020). Vietnam's Coronavirus Struggle: Managing the Economic Impact. Retrieved July 5, 2020, from https://thediplomat.com/2020/03/vietnams-coronavirus-struggle-managing-the-economic-impact/

Nikkei Asia. (2020). Thai central bank cuts 2020 GDP outlook to negative $8.1 \%$. Retrieved July 18, 2020, from https://asia.nikkei.com/Economy/Thai-central-bank-cuts-2020-GDP-outlook-to-negative-8.1

Novika, S. (2020). Di Depan DPR, Mentan Ngeluh Ekspor-Impor Pangan Terganggu Corona. Retrieved July 16, 2020, from https://finance.detik.com/berita-ekonomi-bisnis/d-4902563/ di-depan-dpr-mentan-ngeluh-ekspor-impor-pangan-terganggu-corona

Nytimes. (2020). Thailand Ends Curfew. Retrieved July 13, 2020, from https://www.nytimes. com/reuters/2020/06/15/world/asia/15reuters-health-coronavirus-thailand.html

Ogilvie, D., \& Hauge, F. (1998). Strategic Decision Making: A Creative Action-Based Approach. Academy of Management Proceedings. https://doi.org/10.5465/apbpp.1998.27667000

Onishi, T. (2020). Vietnam locks down Son Loi district near Hanoi for 20 days. Retrieved July 13, 2020, from https://asia.nikkei.com/Spotlight/Coronavirus/Vietnam-locks-down-SonLoi-district-near-Hanoi-for-20-days

Open Development Mekong. (2020). Environment and natural resources. Retrieved July 17, 2020, from https://opendevelopmentmekong.net/topics/environment-and-natural-resources/

Our World in Data. (2020). COVID-19: Government Stringency Index, Jun 21, 2020. Retrieved July 14, 2020, from https://ourworldindata.org/grapher/covid-stringency-index?tab=chart\&stackMode=absolute\&time=2020-06-21\&country=IDN THA VNM\&region=Asia

Paweewun, O. (2020). IMF: Thai GDP down 6.7\%. Retrieved July 18, 2020, from https://www. bangkokpost.com/business/1900795/imf-thai-gdp-down-6-7\#: :text=The IMF downgraded the economic, multinational lender's projection holds true.\&text=The IMF in January predicted,year and $3.5 \% 25$ in 2021

Penh, P. (2020). Coronavirus: Vietnam upbeat about economic recovery. Retrieved July 12, 2020, from https://www.dw.com/en/coronavirus-vietnam-upbeat-about-economic-recovery/a-53531222 
Peterson, E. W. F. (2017). The role of population in economic growth. SAGE Open, 7(4). https:// doi.org/10.1177/2158244017736094

Piketty, T. (2015). About capital in the twenty first century. American Economic Review, 105(5), 48-53. https://doi.org/10.1257/aer.p20151060

Pranita, E. (2020). MHKI Desak Pemerintah Segera Cairkan Biaya Perawatan Pasien Corona. Retrieved July 12, 2020, from https://www.kompas.com/sains/ $\mathrm{read} / 2020 / 04 / 20 / 124812623 / \mathrm{mhki}$-desak-pemerintah-segera-cairkan-biaya-perawatan-pasien-corona

Prebisch, R. (1950). The economic development of Latin America and its principal problems.

Public Health Quality Forum. (2008). Consensus Statement on Quality in the Public Health System. Retrieved July 8, 2020, from https://www.apha.org/-/media/files/pdf/topics/ qi/phqf_consensus_statement_92208.ashx?la=en\&hash=4602FEE2A5D675183FB2BA6F62404B9101349F0A\#: :text=To promote uniformity across the, the population can be healthy.

Pusparisa, Y. (2020). Puluhan Dokter Meninggal dalam Pandemi Covid-19. Retrieved July 12, 2020, from https://databoks.katadata.co.id/datapublish/2020/04/21/puluhan-dokter-meninggal-dalam-pandemi-covid-19

Putri, C. A. (2020). PSBB Berlaku per Hari Ini, Apa Dampaknya ke Ekonomi Jakarta? Retrieved July 16, 2020, from https://www.cnbcindonesia.com/news/20200410061039-4-151038/ psbb-berlaku-per-hari-ini-apa-dampaknya-ke-ekonomi-jakarta

Rahman, D. F. (2020a). Activists criticize Jakarta for lack of emissions data transparency. Retrieved July 13, 2020, from https://www.thejakartapost.com/news/2020/03/11/activists-criticize-jakarta-for-lack-of-emissions-data-transparency.html

Rahman, D. F. (2020b). Indonesia records FDI decrease in second consecutive quarter. Retrieved July 25, 2020, from https://www.thejakartapost.com/news/2020/07/22/indonesia-records-fdi-decrease-in-second-consecutive-quarter.html

Ritchie, H., Ortiz-Ospina, E., Beltekian, D., Mathieu, E., Hasell, J., Macdonald, B., ... Roser, M. (2020a). Coronavirus (COVID-19) Cases. Retrieved July 18, 2020, from https://ourworldindata.org/covid-cases?country=IND USA GBR CAN DEU FRA\#weekly-and-biweekly-cases-where-are-confirmed-cases-increasing-or-falling

Ritchie, H., Ortiz-Ospina, E., Beltekian, D., Mathieu, E., Hasell, J., Macdonald, B., ... Roser, M. (2020b). Coronavirus (COVID-19) Deaths. Retrieved July 18, 2020, from https:// ourworldindata.org/covid-deaths?country=IND USA GBR CAN DEU FRA\#total-confirmed-deaths-how-rapidly-have-they-increased-compared-to-other-countries

Rubalcava, L. N., \& Teruel, G. M. (2004). The role of maternal cognitive ability on child health. Economics and Human Biology, 2(3), 439-455. https://doi.org/10.1016/j.ehb.2004.10.009

Saigoneer. (2019). Vietnam's Obesity Rates Increased the Fastest in Southeast Asia in 5 Years. Retrieved July 8, 2020, from https://saigoneer.com/saigon-health/16988-vietnam-s-obesity-rates-increased-the-fastest-in-southeast-asia-in-5-years\#: :text=A different study in 2017, at 1 in 10 people

Septiari, D. (2020). Fearing economic toll from COVID-19, RI tables "travel bubble" proposal. 
Retrieved July 14, 2020, from https://www.thejakartapost.com/news/2020/06/26/fearing-economic-toll-from-covid-19-ri-tables-travel-bubble-proposal.html

Shira, D. (2020). Vietnam Business Operations and the Coronavirus: Updates. Retrieved July 14, 2020, from https://www.vietnam-briefing.com/news/vietnam-business-operations-and-the-coronavirus-updates.html/

Siallagan, W. A. (2020). Redam Kesulitan Ekonomi Akibat COVID-19, Pemerintah Lakukan Upaya Ini. Retrieved July 24, 2020, from https://www.kemenkeu.go.id/publikasi/artikel-dan-opini/redam-kesulitan-ekonomi-akibat-covid-19-pemerintah-lakukan-upaya-ini/

Singer, H. . (1950). The Distribution of Gains Between Borrowing and Investing Nations. American Economic Association, 40(2), 473-485.

Statista. (2020). Total contribution of travel and tourism to the GDP in Southeast Asia from 2010 to 2019. Retrieved July 4, 2020, from https://www.statista.com/statistics/1102510/ southeast-asia-travel-and-tourism-gdp-contribution/\#: :text=In 2019\%2C the travel and, in Southeast Asia in 2010

Statista Research Department. (2020a). GDP projection after COVID-19 outbreak in Vietnam 2020. Retrieved July 18, 2020, from https://www.statista.com/statistics/1103423/vietnam-gdp-projection-after-covid-19/

Statista Research Department. (2020b). Impact of the coronavirus pandemic on the global economy - Statistics \& Facts. Retrieved July 15, 2020, from https://www.statista.com/ topics/6139/covid-19-impact-on-the-global-economy/

Sukirno. (2006). Makroekonomi Teori Pengantar. Jakarta: PT Raja Grafindo Persada.

Sukirno, S. (2008). Makroekonomi. Jakarta: PT. Raja Grafindo Persada.

Sutrisno, B. (2020). 50 days of Indonesia's partial lockdown. Is it enough for the 'new normal'? Retrieved July 18, 2020, from https://www.thejakartapost.com/news/2020/05/28/50days-of-indonesias-partial-lockdown-is-it-enough-for-the-new-normal.html

Tarigan, R. (2006). Perencanaan Pembangunan Wilayah. Jakarta: Bumi Aksara.

Tekic, Z., \& Katalinic, B. (2012). THE MISSING LINK - KNOWLEDGE CREATION AND INNOVATION. In Annals \& Proceedings of DAAAM International (pp. 0229-0232). Retrieved from https://daaam.info/Downloads/Pdfs/proceedings/proceedings_2012/0229_Tekicatal. pdf

Thai, E. (2020). Leading through COVID: Investing in Vietnam's Future. Retrieved July 18, 2020, from https://insights.som.yale.edu/insights/leading-through-covid-investing-in-vietnam-s-future

Thai PBS World. (2020). Thailand's impressive battle against COVID-19 result of decades-long efforts. Retrieved July 12, 2020, from https://www.thaipbsworld.com/thailands-impressive-battle-against-covid-19-result-of-decades-long-efforts-2/

Thaichareon, K. (2020). Thai exports may decline $1.5 \%$ this year on virus impact - shippers' council. Retrieved July 17, 2020, from https://www.nasdaq.com/articles/thai-exportsmay-decline-1.5-this-year-on-virus-impact-shippers-council-2020-03-03

Thailand Board of Investment. (2020). Board of Investment's New Campaign Highlights Thai- 
land's Resilience. Retrieved July 12, 2020, from https://www.boi.go.th/index.php?page=press_releases_detail\&topic_id=125494

Thanthong-Knight, R. (2020). Thailand to Impose Broad Lockdown to Fight Novel Coronavirus. Retrieved July 14, 2020, from https://www.bloomberg.com/news/articles/2020-03-25/ thailand-to-impose-broad-lockdown-to-fight-spread-of-coronavirus

The ASEAN Post Team. (2019). Freedom for ASEAN's ageing population. Retrieved July 18, 2020, from https://theaseanpost.com/article/freedom-aseans-ageing-population

The ASEAN Post Team. (2020). Southeast Asia's rapidly ageing population. Retrieved July 18, 2020, from https://theaseanpost.com/article/southeast-asias-rapidly-ageing-population

The ASEAN Secretariat. (2019). ASEAN Key Figures 2019. Retrieved from https://www.aseanstats.org/wp-content/uploads/2019/11/ASEAN_Key_Figures_2019.pdf

The Jakarta Post. (2020). Thailand ends curfew, marks 21 days with no local coronavirus cases. Retrieved July 13, 2020, from https://www.thejakartapost.com/seasia/2020/06/15/thailand-ends-curfew-marks-21-days-with-no-local-coronavirus-cases.html

The Japan Times. (2020). Virus gives embattled Thai premier chance to consolidate power. Retrieved July 1, 2020, from https://www.japantimes.co.jp/news/2020/04/10/asia-pacific/ politics-diplomacy-asia-pacific/prayut-chan-ocha-thailand-coronavirus/\#.Xw3P75MzZfQ

The Nation Thailand. (2020). Toyota latest automaker to suspend production as some plants. Retrieved July 18, 2020, from https://www.nationthailand.com/auto/30385082?utm_ source=homepage\&utm_medium=internal_referral\#: :text=Toyota Motor (Thailand) announced it,by the Covid-19 crisis.\&text=The three factories are in,automaker's Gateway facility in Chachoengsao

The World Bank. (2020a). Ease of Doing Business Scores. Retrieved July 18, 2020, from https:// www.doingbusiness.org/en/data/doing-business-score

The World Bank. (2020b). The World Bank In Indonesia. Retrieved July 18, 2020, from https:// www.worldbank.org/en/country/indonesia/overview

Theparat, C. (2020). NESDC: $14.4 \mathrm{~m}$ workers at risk. Retrieved July 17, 2020, from https://www. bangkokpost.com/business/1925808/nesdc-14-4m-workers-at-risk

Thu Vien Phap Luat. (2020a). Decision No 15/2020/QD-TTg. Retrieved July 14, 2020, from https://thuvienphapluat.vn/van-ban/lao-dong-tien-luong/Quyet-dinh-15-2020-QD-TTgho-tro-nguoi-dan-gap-kho-khan-do-dich-COVID19-441047.aspx

Thu Vien Phap Luat. (2020b). Resolution No. 42/NQ-CP. Retrieved July 14, 2020, from https:// thuvienphapluat.vn/van-ban/lao-dong-tien-luong/Resolution-\%0942-NQ-CP-2020-assistance-for-people-affected-by-Covid-19-pandemic-439660.aspx

Todaro, P. (2000). Pembangunan ekonomi di dunia ketiga. Jakarta: Erlangga.

Todd Pollac, G. T. (2020). Emerging COVID-19 success story: Vietnam's commitment to containment. Retrieved July 13, 2020, from https://ourworldindata.org/covid-exemplar-vietnam

Trading Economics. (2020). Vietnam GDP Annual Growth Rate. https://tradingeconomics. com/vietnam/gdp-growth-annual 
Trang, T. (2020). Deputy Prime Minister Vu Duc Dam: Immediately implement the medical declaration at all border gates. Retrieved July 14, 2020, from http://www.hanoimoi.com. vn/tin-tuc/Suc-khoe/956398/pho-thu-tuong-vu-duc-dam-thuc

UNESCO. (2013). Culture: a Driver and Enabler of Social Cohesion. Retrieved July 12, 2020, from http://www.unesco.org/new/fileadmin/MULTIMEDIA/HQ/CLT/images/CultureDriverEnablerSocialCohesionENG.pdf

Varagur, K. (2020). Indonesia's government was slow to lock down, so its people took charge. Retrieved July 18, 2020, from https://www.nationalgeographic.com/history/2020/05/indonesia-government-slow-lock-down-people-took-charge/

Vilailert, P. (2020). The Thai Tourist Industry Wrecked, Despite Success in Controlling COVID-19. Retrieved July 4, 2020, from https://www.indepthnews.net/index.php/the-world/asiapacific/3596-the-thai-tourist-industry-wrecked-despite-success-in-controlling-covid-19

Virgil, D., Selo, F. A. R., \& Angdreas, K. (2020). Indonesia's Pre-Employment Card Program: What It Fails In Human Rights Issues Amid COVID-19 Pandemic - Analysis. Retrieved July 13, 2020, from https://www.eurasiareview.com/28042020-indonesias-pre-employmentcard-program-what-it-fails-in-human-rights-issues-amid-covid-19-pandemic-analysis/

VOA News. (2020). Vietnam Poised to Export COVID-19 Test Kits. Retrieved July 12, 2020, from https://www.voanews.com/covid-19-pandemic/vietnam-poised-export-covid-19test-kits

Voice of Vietnam. (2019). Rising labor costs erode Vietnam's appeal to foreign investors. Retrieved July 18, 2020, from https://vov.vn/en/economy/rising-labor-costs-erode-vietnams-appeal-to-foreign-investors-397477.vov

Vu, K., Nguyen, P., \& Pearson, J. (2020). After aggressive mass testing, Vietnam says it contains coronavirus outbreak. Retrieved July 13, 2020, from https://www.reuters.com/article/ us-health-coronavirus-vietnam-fight-insi-idUSKBN22B34H

Vu, M., \& Tran, B. T. (2020). The Secret to Vietnam's COVID-19 Response Success. Retrieved July 8, 2020, from https://thediplomat.com/2020/04/the-secret-to-vietnams-covid-19response-success/

WHO. (2001). Macroeconomics and Health: Investing in Health for Economic Development. Retrieved from https://www.who.int/pmnch/knowledge/topics/2001_who_cmh/en/

WHO. (2020a). Indonesia Ministry of Health Officials visit Thailand on COVID-19 emergency response. Retrieved July 12, 2020, from https:// www.who.int/indonesia/news/detail/09-03-2020-indonesia-ministry-of-health-officials-visit-thailand-on-covid-19-emergency-response

WHO. (2020b). Pneumonia of unknown cause -China. Disease outbreak news: 5 January 2020.

World Bank. (2020a). Global Outlook: Pandemic, Recession: The Global Economy in Crisis.

World Bank. (2020b). World Health Organization's Global Health Workforce Statistics. Retrieved July 12, 2020, from https://data.worldbank.org/indicator/SH.MED.BEDS.ZS

Xinhua. (2018). Vietnam's HCM City spots 12 H1N1 patients. Retrieved July 8, 2020, from http://www.xinhuanet.com/english/2018-06/23/c_137275805.html 
Wicaksono, R. M. T. I Economic Determinants of Growth Acceleration During Covid-19 Pandemic: A Comparative Study Between IndoneA. D., et al.

Yuvejwattana, S., Thanthong-Knight, R., \& Nguyen, A. (2020). Thailand Plans $\$ 30.5$ Billion Borrowing for Latest Stimulus. Retrieved July 14, 2020, from https://www.bloomberg.com/news/ articles/2020-04-07/thailand-plans-30-5-billion-in-new-borrowing-for-major-stimulus 